\title{
Arcjet Testing of Micro-Meteoroid Impacted Thermal Protection Materials
}

\author{
Parul Agrawal ${ }^{1}$ \\ ERC Inc., C/O NASA Ames Moffett Field, CA, 94035 \\ Michelle M. Munk ${ }^{2}$, Louis A. Glaab ${ }^{3}$ \\ NASA Langley Research Center, Hampton, VA 23681
}

There are several harsh space environments that could affect thermal protection systems and in turn pose risks to the atmospheric entry vehicles. These environments include micrometeoroid impact, extreme cold temperatures, and ionizing radiation during deep space cruise, all followed by atmospheric entry heating. To mitigate these risks, different thermal protection material samples were subjected to multiple tests, including hyper velocity impact, cold soak, irradiation, and arcjet testing, at various NASA facilities that simulated these environments. The materials included a variety of honeycomb packed ablative materials as well as carbon-based non-ablative thermal protection systems. The present paper describes the results of the multiple test campaign with a focus on arcjet testing of thermal protection materials. The tests showed promising results for ablative materials. However, the carbon-based non-ablative system presented some concerns regarding the potential risks to an entry vehicle. This study provides valuable information regarding the capability of various thermal protection materials to withstand harsh space environments, which is critical to sample return and planetary entry missions.

\section{Nomenclature}

$\begin{array}{ll}\text { AHF } & =\text { Aerodynamic heating facility } \\ \text { ARA } & =\text { Applied Research Associates } \\ \text { C-C } & =\text { Carbon-Carbon } \\ \text { CFD } & =\text { Computation fluid dynamics } \\ \text { CT } & =\text { Computed Tomography } \\ \text { EVT } & =\text { Entry vehicle technology } \\ \text { IHF } & =\text { Interaction heating facility } \\ \text { IR } & =\text { Infrared } \\ \text { ISPT } & =\text { In-space Propulsion Technology } \\ \text { MMOD } & =\text { Micrometeoroid orbital debris } \\ \text { MSFC } & =\text { Marshall Space Flight Center } \\ \text { MSR } & =\text { Mars sample return } \\ \text { SEE } & =\text { Space environment effects } \\ \text { TPS } & =\text { Thermal protection system } \\ \text { WSTF } & =\text { White Sand Testing Facility }\end{array}$

\section{Introduction}

$\mathrm{N}$ ASA's In-Space Propulsion Technology Program (ISPT) is developing several critical technologies that can decrease mass, flight duration and cost to significantly enhance or enable planetary science missions. Design

\footnotetext{
${ }^{1}$ Senior Research Scientist, Thermal Protection Materials Branch, MS 234-1, NASA Ames Research Center, AIAA Sr. Member.

2 ISPT Entry Vehicle Project Manager, 1 North Dryden Street, MS 489, NASA Langley Research Center, AIAA Sr. Member .

3 MMEEV Project Manager, 1 North Dryden Street, MS 489, NASA Langley Research Center, AIAA member.
} 
and development of entry vehicles is identified among the mission enabling technologies. The Entry Vehicle Technology (EVT) project under the ISPT program includes development and maturation of the aerocapture phase; a process of slowing down the vehicle by using the entry atmosphere and placing it into an orbit. ${ }^{1,2}$ To mature aerocapture technology, a study was conducted in 2006 for ISPT program to identify the space environments and their potential effects on an aerocapture vehicle. The results from that study identified micrometeoroids hits to the vehicle, cold soak experienced during a deep space interplanetary cruise, ionizing radiation due to solar flares, and atmospheric entry heating as the severe environments that an aerocapture vehicle may need to endure and survive $\mathrm{e}^{3,4}$. Based on the study, four key tests were identified as part of Space Environment Effects (SEE) test campaign that would represent the exposure of an entry vehicle to the space environments to simulate deep space interplanetary cruise followed by an atmospheric entry:

1. Exposure to cold soak

2. Exposure to ionizing radiation

3. Hypervelocity Impact Testing 5

4. Arcjet Testing

Results from this study provide critical information towards the development of aerocapture technology. In addition, results from this work are also applicable to all atmospheric entry vehicles.

Four different Thermal Protection System (TPS) materials were identified as aerocapture candidates to be selected for the testing. These materials included honeycomb packed ablator systems, as well as a carbon-carbon hot structure. A brief description of the materials is provided in Section II of this paper. In order to avoid a very large sample set for this test campaign, it was decided to expose each material sample to multiple environments. This process enabled efficient use of the TPS materials and represented the sequence of the most extreme environment that thermal protection materials in an entry vehicle would encounter. A description of the test campaign is provided in Section III. These tests were performed at different NASA facilities. The exposure to radiation was conducted at Marshall Space Flight Center (MSFC). Subsequently, the samples were kept in a cold shroud and subjected to hyper-velocity impact at NASA's White Sands Testing Facility (WSTF) in New Mexico. The last leg of the test campaign involved arcjet testing to simulate entry environments, and this was conducted at NASA Ames Research Center (ARC). The present paper focuses on the details of this last, critical leg of the testing and summarizes the results from pre- and post- arcjet test laser scans focusing on changes in test articles, computed tomography (CT) scans, infrared and thermocouple temperature measurements during the test. The effectiveness of each of the candidate materials in space like environments is evaluated as part of this study.

\section{TPS Material Candidates}

Several different TPS materials were considered for evaluation under this test campaign. These included honeycomb packed ablators as well as carbon-carbon hot structures. Broadly, based on their capability to withstand heat flux magnitude, the materials were categorized as: forebody TPS and aftbody (backshell) TPS.

The forebody candidate materials are able to withstand heat flux greater than $600 \mathrm{~W} / \mathrm{cm}^{2}$. Based on the mission, the heat flux on the forebody materials could range from $250 \mathrm{~W} / \mathrm{cm}^{2}-1000 \mathrm{~W} / \mathrm{cm}^{2}$ and above. Two different types of forebody materials were chosen. The first was honeycomb packed Phencarb family of materials from Applied Research Associates (ARA) Ablative Laboratory. This material consists of phenolic resin, reinforcing fibers, and low-density fillers, and is typically packed in large honeycomb cell. ${ }^{6}$ The second material was CarbonCarbon TPS system from Lockheed Martin, similar to what was used in Genesis probe. ${ }^{7}$ This TPS is comprised of a thin carbon-carbon facesheet attached (through co-processing) to low-density carbon fiberform insulation. ${ }^{8}$ Table 1 provides the list of materials candidates that were selected for the present test campaign.

The test articles for each of these materials were designed to be compatible with stagnation testing in the arcjets. These articles were flat faced cylinders with $10.16 \mathrm{~cm}$ diameter. Figure 1 shows pictures of test articles from each of the materials. The Carbon-Carbon hot structure system was made with a $10.0 \mathrm{~cm}$ diameter, thin hollow cylindrical carbon-carbon shell. A porous carbon fiber based preform insulation, Calcarb, was bonded to the outer shell as shown in Figure 2. The dimensions of all the forebody candidates are provided in Table 1.

The aftbody candidate materials were those that could not withstand heat flux above $300 \mathrm{~W} / \mathrm{cm}^{2}$. These materials were chosen from two families of ablators. The first one was SLA-561V, a low density cork silicone ablator produced by Lockheed Martin with phenolic honeycomb support structure. This material's heritage dates back to the Mars Viking and Pathfinder missions and most recently has been used as the backshell material for the Mars Science 
Laboratory mission. ${ }^{9}$ Figure 3a shows the picture of SLA-561V test sample that has been subjected to hypervelocity impact test at WSTF. The samples were outfitted with Silicone Impregnated Reusable Ceramic Ablator (SIRCA) collars to make the dimensions and profile compatible for stagnation testing in the arcjets. The second family of ablator consisted of silicone-based SRAM ablators from ARA. This material consists of a silicone-based resin system with silica micro-balloons and other fillers in a honeycomb support structure. ${ }^{6}$ Figure $3 \mathrm{~b}$ shows the test article made with this ablator. All the backshell TPS test articles were flat faced cylinders with $12.7 \mathrm{~cm}$ in diameter. The dimension of each sample is listed in Table 1.

Each forebody and aftbody test articles had two thermocouples attached at the interface of the TPS sample and aluminum back plate to measure the temperature during cold soak and arcjet testing.

Table 1: Candidate materials for SEE test campaign.

\begin{tabular}{|c|c|c|c|c|c|c|}
\hline \multirow{2}{*}{ Phencarb } & Phencarb-24 & \multirow{2}{*}{$\begin{array}{l}\text { ARA Ablative } \\
\text { Lab }\end{array}$} & 5 & 2.54 & 10.16 & \multirow{3}{*}{$\begin{array}{l}\text { Foebody } \\
\text { Candidate }\end{array}$} \\
\hline & Phencarb-28 & & 5 & 2.54 & 10.16 & \\
\hline Carbon-Carbon & $\begin{array}{l}\text { Carbon-Carbon } \\
\text { Shell with Calcarb } \\
\text { insulator }\end{array}$ & $\begin{array}{l}\text { Lockheed } \\
\text { Martin }\end{array}$ & 11 & 8.89 & 10.00 & \\
\hline \multirow{3}{*}{ SRAM } & SRAM-14 & \multirow{3}{*}{$\begin{array}{l}\text { ARA Ablative } \\
\text { Lab }\end{array}$} & 4 & 1.27 & 12.70 & \multirow{4}{*}{$\begin{array}{l}\text { Backshell } \\
\text { Candidat }\end{array}$} \\
\hline & SRAM-14 & & 4 & 2.54 & 12.70 & \\
\hline & SRAM-20 & & 4 & 2.54 & 12.70 & \\
\hline SLA & SLA-561V & $\begin{array}{l}\text { Lockheed } \\
\text { Martin }\end{array}$ & 4 & 1.27 & 12.70 & \\
\hline
\end{tabular}

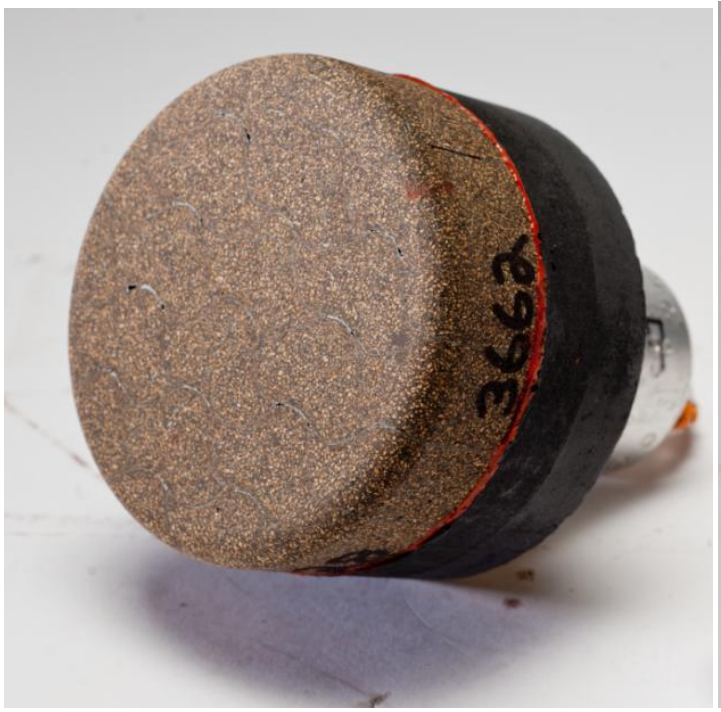

(a)

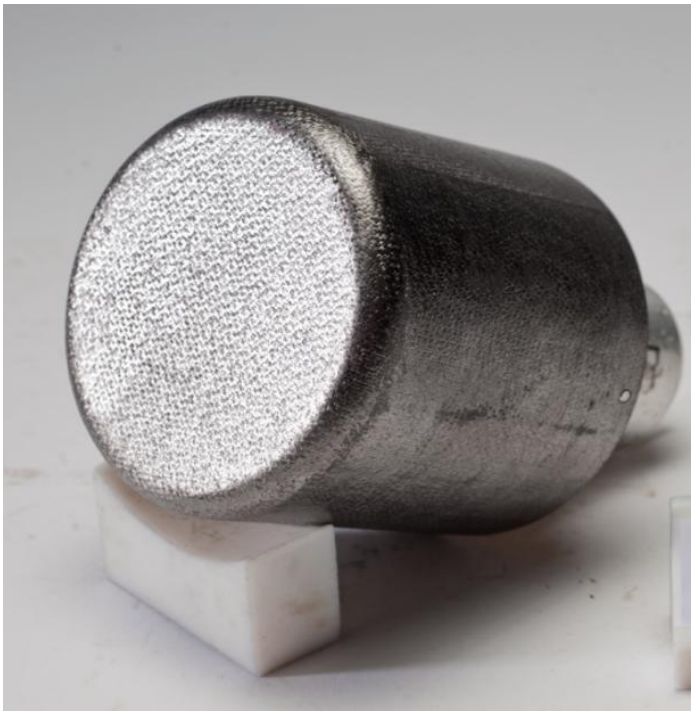

(b)

Figure 1. Forebody Candidates. (a) Phencarb (b) Carbon-Carbon System 


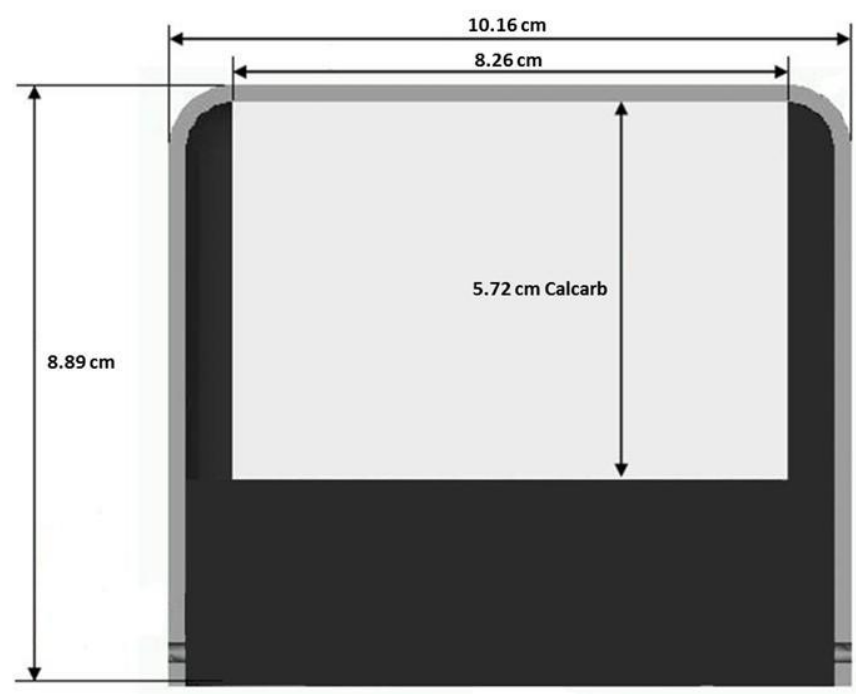

Figure 2: Carbon-Carbon system.

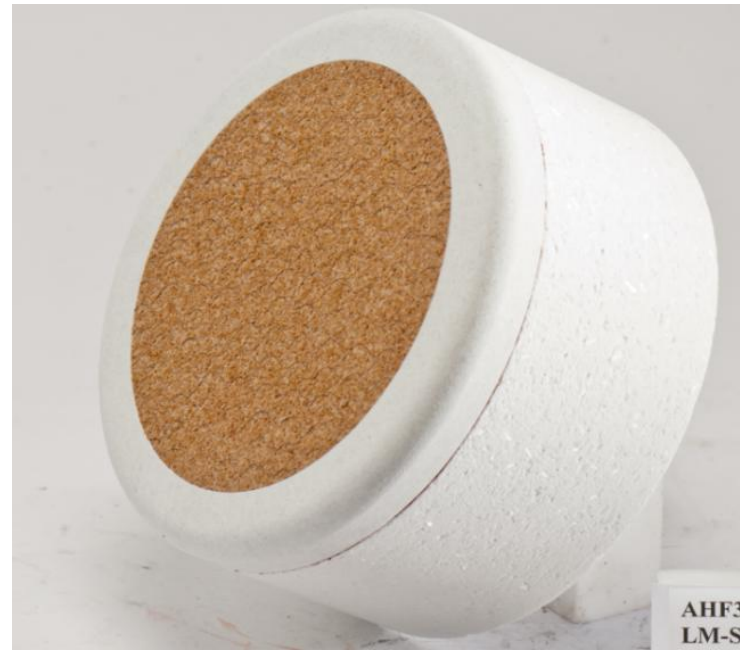

(a)

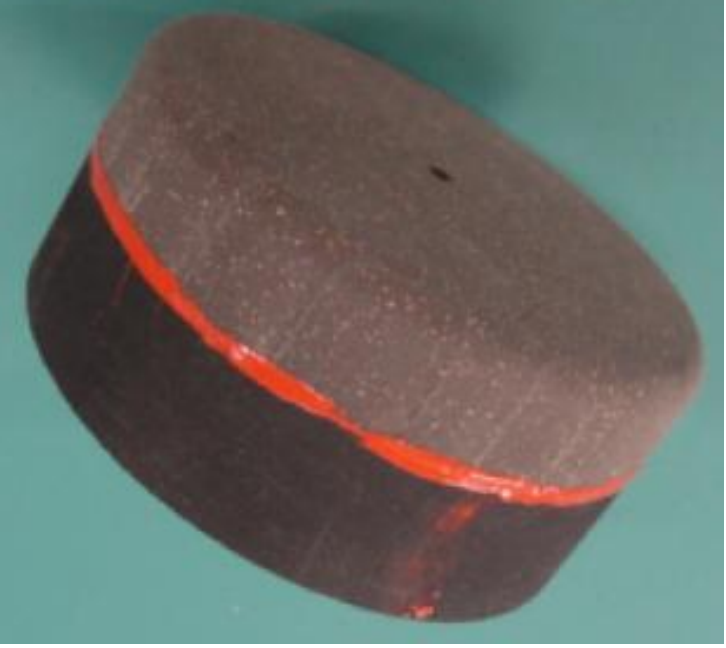

(b)

Figure 3. Aftbody candidates. (a) SLA-561V (b) SRAM-20

\section{Test Campaign}

The test campaign included several tests to best simulate the severe environments to which TPS materials could be exposed during an interplanetary mission or return to Earth. Each sample was exposed to multiple tests at various NASA facilities in the order listed:

- Irradiation

- Hyper velocity impact testing on samples kept at cryogenic temperature

- Arcjet testing

The exposure to radiation was conducted for half of the samples at Marshall Space Flight Center (MSFC). The radiation exposure was accomplished using the Pelletron accelerator-based system located in the MSFC Space Environmental Effects Facility. A National Electrostatics Corporation Model 7.5SH Pelletron accelerator produced the $2 \mathrm{MeV}$ electrons. Each material was radiated with a nominal $10 \mathrm{MRad}$ dose at the surface. Following this test, all the samples were taken to NASA's White Sands Testing Facility (WSTF), where they were subjected to the hypervelocity impact while maintaining a cryogenic temperature below $77 \mathrm{~K}$. Figure 4 shows the pictures of the cryogenic setup and gas gun at White Sands. This leg of the test campaign represents the micro-meteoroid orbital 
debris (MMOD) hit to the vehicle during deep space cruise. A $1.0 \mathrm{~mm}$ soda lime glass projectile bead was used at nominal $7.0 \mathrm{~km} / \mathrm{sec}$ velocity. All the samples were impacted near the center. Samples were impacted at either 0 degrees or 60 degrees incidence angle to the surface. The temperatures during the impact were recorded with the help of embedded thermocouples. The measurements show that the bondline temperature values ranged from $80 \mathrm{~K}$ 90K. All the ablators survived the impact test without experiencing catastrophic failure. However, four C-C samples experienced separation of the metallic back plate due to a reflective tensile stress wave that was generated after impact and two samples experienced separation of the Calcarb preform from the carbon-carbon layer, probably during the cold soak. These two samples were then set aside and no further testing was performed. All the samples were laser scanned to map the cavities (damage) created by the impact and to provide the baseline information so that cavities could be monitored for any potential growth during the arcjet tests. The length, width, and height of the cavities formed after MMOD test are listed in tables in Section V of this paper. Some of the samples were also subjected to computed tomography (CT) scan to measure the damage after impact and its progress after the arcjet test. Figure 5, 6, 7 and 8 show the CT scan images of samples after the impact test. Each sample shows the formation of a main cavity during the impact. The CT scans do not show evidence of secondary cracking in any of the materials subjected to hypervelocity impact.

The last leg of the test campaign consisted of arcjet testing at NASA Ames Research Center to simulate the atmospheric entry. All the forebody candidates were tested in the $60 \mathrm{MW}$ Interaction Heating Facility (IHF), and the aftbody candidates were tested at the $20 \mathrm{MW}$ Aerodynamic Heating Facility (AHF). The pictures of samples mounted on both the facilities are shown in Figure 9. The details of both the facilities at NASA Ames are provided in References 10 and 11.

The rest of the paper focuses on describing the details of the arcjet test environments, results from tests at both the facilities, discussions and recommendations.
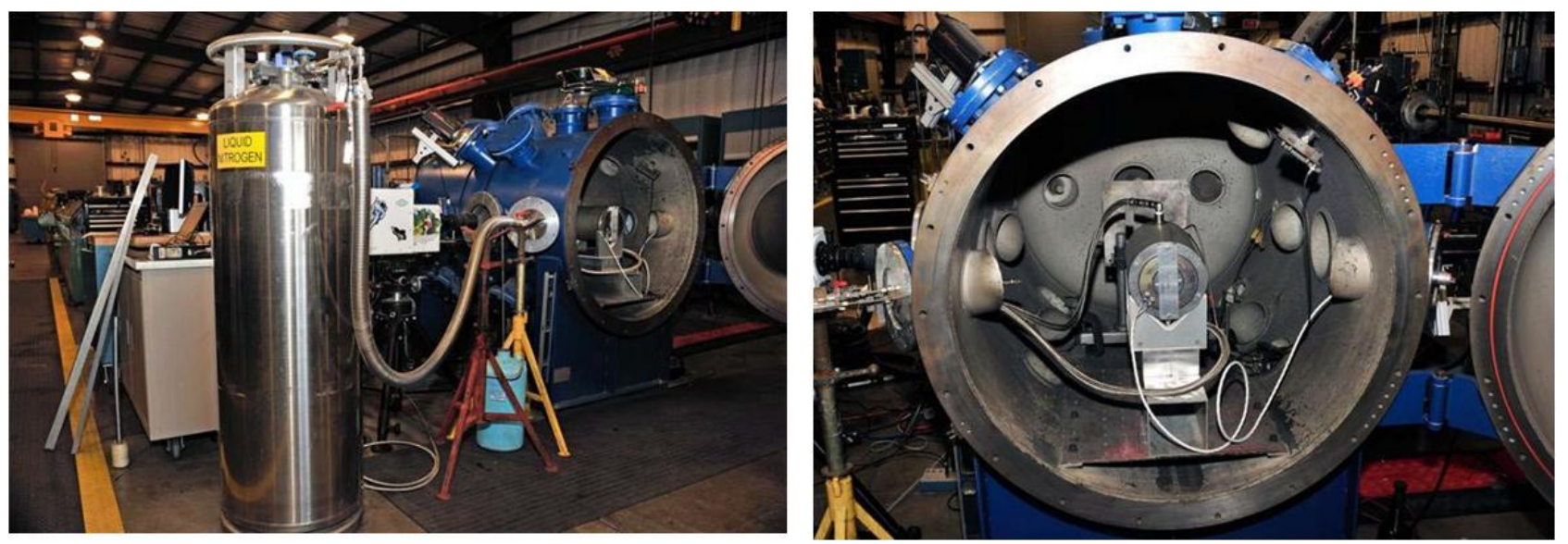

Figure 4. Cryogenic setup at White Sands Test Facility for the hypervelocity impact testing. 

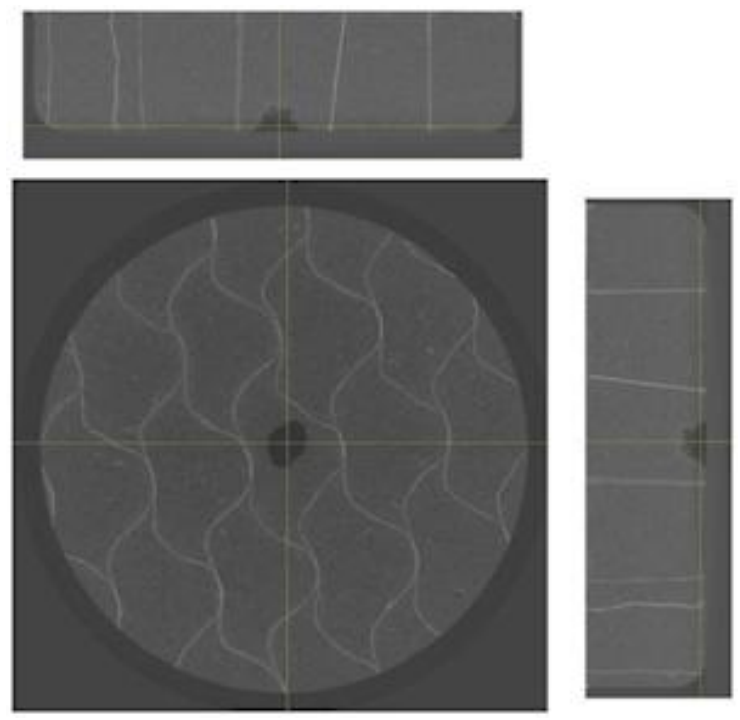

Figure 5: CT scans of Phencarb sample after MMOD test.

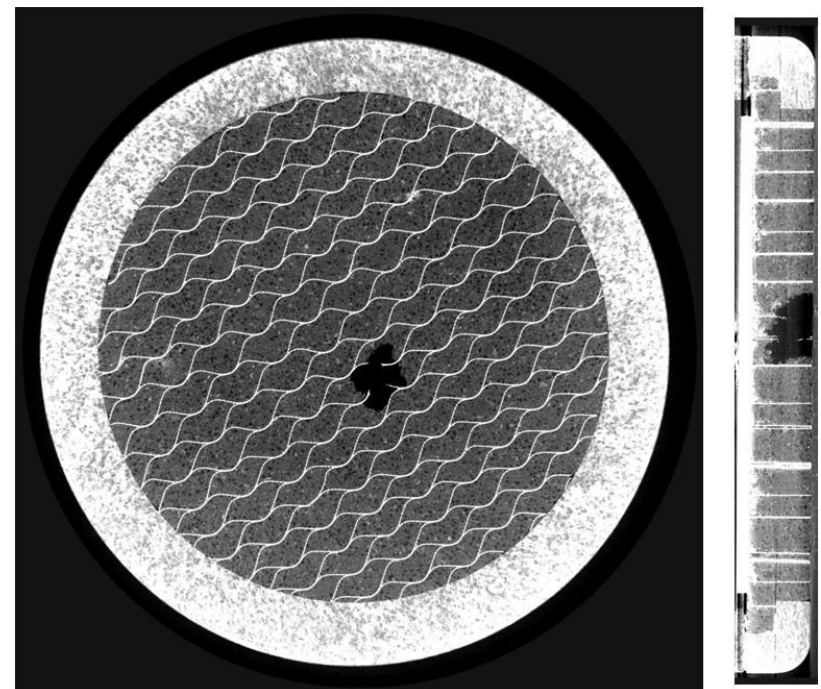

Figure 6: CT scans of SLA sample after MMOD test 

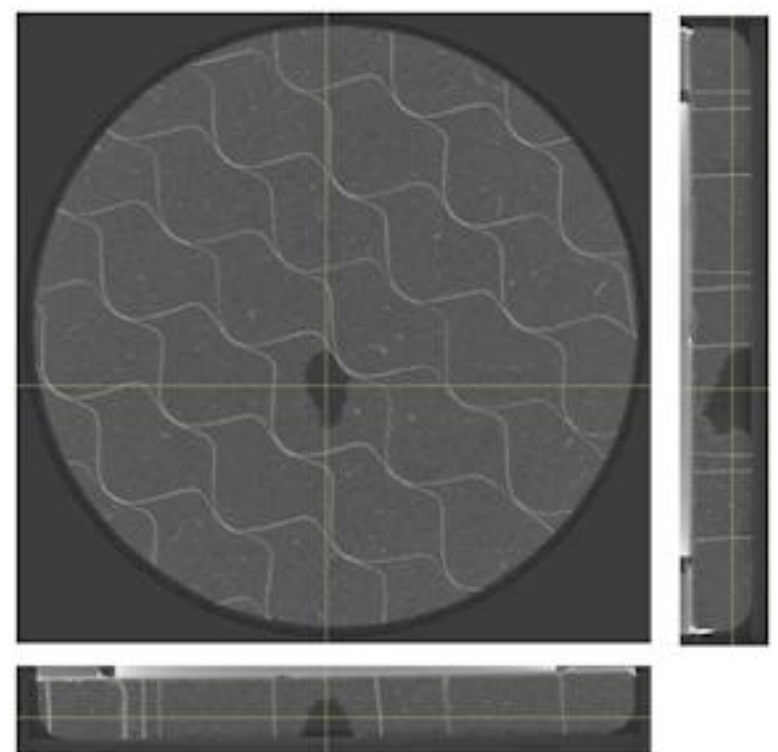

Figure 7: CT scans of SRAM sample after MMOD test

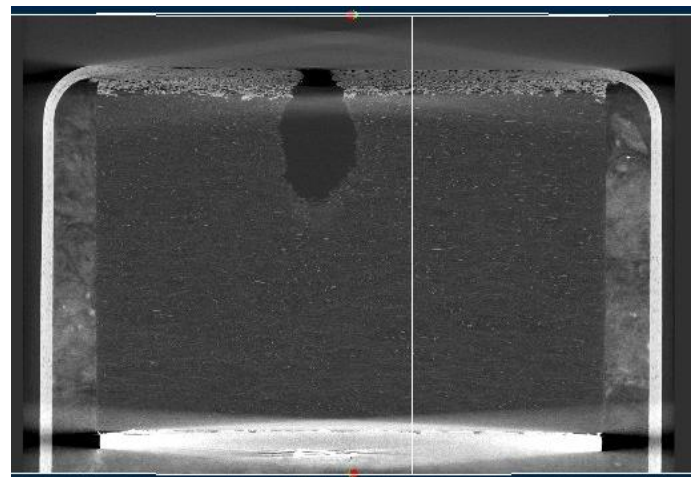

Figure 8: CT scan of a C-C sample after MMOD test.

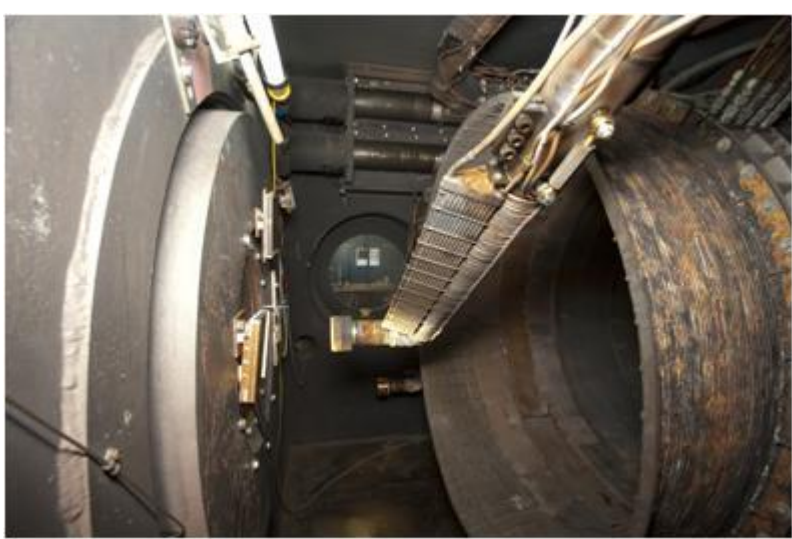

(a)

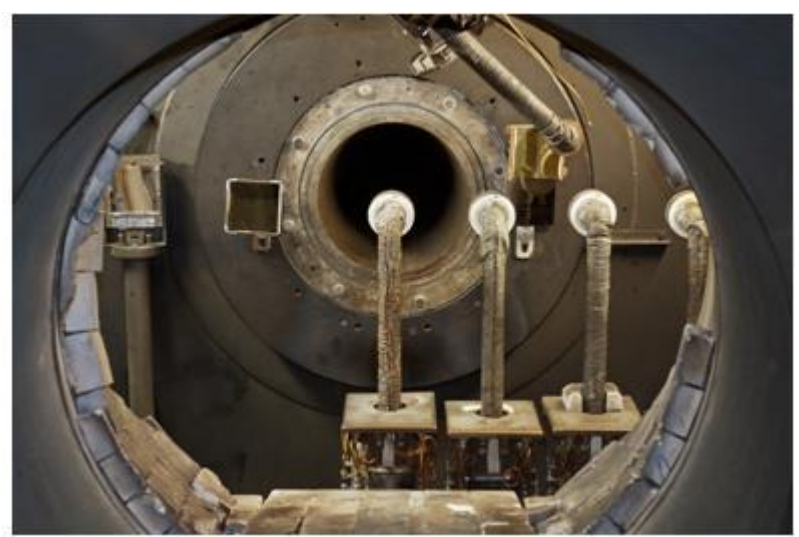

(b)

Figure 9. Articles inside the arcjets for thermal testing. (a) 60 MW IHF (b) 20 MW AHF. 


\section{Arcjet Environments and Test Matrix}

The present test campaign is not tied to a specific NASA mission. Therefore, the environments for arcjet testing were determined by referencing an aerothermal environment from computational fluid dynamics (CFD) analysis for a nominal trajectory of an Earth entry vehicle. ${ }^{12}$ Figure 10 shows the simplified geometry of an Earth entry vehicle. Figure 11 shows the peak heat flux and corresponding pressure profile for this geometry for a given Mars Sample Return (MSR) mission type trajectory. The peak stagnation heat flux at the nose is about $1000 \mathrm{~W} / \mathrm{cm}^{2}$. Near the shoulder area, where the likelihood of occurrence of MMOD type damage is greatest, the heat flux reduces by $50 \%$. The pressure at the fore body is between $30-40 \mathrm{kPa}$. Therefore, for the forebody materials, $500 \mathrm{~W} / \mathrm{cm}^{2}$ heat flux and $30 \mathrm{kPa}$ pressure were chosen as the nominal test condition in the IHF. Based on the CFD analysis the heat flux magnitude prediction at the backshell is below $50 \mathrm{~W} / \mathrm{cm}^{2}$, and pressure is lower than $300 \mathrm{~Pa}$. As it was not possible to achieve such low pressure inside the arcjet facility, we decided to use $60 \mathrm{~W} / \mathrm{cm}^{2}$ heat flux and $3 \mathrm{kPa}$ pressure as the nominal condition for the aftbody TPS material candidates. Table 2 provides the details for each of the test environments. The plasma exposure times for all the materials were estimated based on their capability to withstand heating (without raising the bondline temperature above the limit) and the calculated heat loads from the trajectory near the shoulder and backshell area. The heat load varied between $5.0 \mathrm{~kJ} / \mathrm{cm}^{2}$ to $40.0 \mathrm{~kJ} / \mathrm{cm}^{2}$. Based on this, the estimates for exposure time for forebody materials could vary from 10 seconds to 80 seconds. All the carbon-carbon samples, except one, were exposed for 30 seconds. One of the samples was exposed for 40 seconds to investigate the effects of longer exposure on the cavity growth. For the backshell candidates, the exposure times in the AHF were determined based on material capability. The test matrix for both forebody and backshell candidates is provided in Table 3.

Table 2: Arcjet Test Environments

\begin{tabular}{|c|c|c|c|c|c|}
\hline Test Condition & $\begin{array}{c}\text { Target } \\
\text { Cold Wall } \\
\text { Heat flux } \\
\left(\mathbf{W} / \mathbf{c m}^{2}\right)\end{array}$ & $\begin{array}{c}\text { Stagnation } \\
\text { pressure } \\
(\mathbf{k P a})\end{array}$ & $\begin{array}{c}\text { Estimated } \\
\text { centerline } \\
\text { enthalpy } \\
(\mathbf{M J} / \mathbf{k g})\end{array}$ & Facility & $\begin{array}{c}\text { nozzle size } \\
(\mathbf{c m})\end{array}$ \\
\hline 1 & $\mathbf{5 0 0}$ & $\mathbf{3 0 . 0}$ & 26 & IHF & 33.02 \\
\hline 2 & $\mathbf{6 0}$ & $\mathbf{3 . 0}$ & 11 & AHF & 45.72 \\
\hline
\end{tabular}

Table 3: Arcjet test matrix

\begin{tabular}{|c|c|c|c|c|c|c|}
\hline Materials & Quantities & \begin{tabular}{|c|} 
TPS \\
Thickness
\end{tabular} & $\begin{array}{c}\text { Test } \\
\text { Condition }\end{array}$ & Facility & TCs & Exposure Time \\
\hline Phencarb-24 & 5 & $1.0 \mathrm{in}$ & 1 & $\mathrm{IHF}$ & $\begin{array}{l}2 \text { Type K } \\
\text { (bondline) }\end{array}$ & $60 \mathrm{sec}$ \\
\hline Phancarb 28 & 5 & $1.0 \mathrm{in}$ & 1 & $\mathrm{IHF}$ & $\begin{array}{l}2 \text { Type K } \\
\text { (bondline) }\end{array}$ & $60 \mathrm{sec}$ \\
\hline $\begin{array}{l}\text { Carbon- } \\
\text { carbon }\end{array}$ & 11 & System & 1 & $\mathrm{IHF}$ & $\begin{array}{l}2 \text { Type K } \\
\text { (bondline) }\end{array}$ & $30 \mathrm{sec}, 1$ sample at $40 \mathrm{sec}$ \\
\hline SRAM-14 & 4 & 0.5 in & 2 & AHF & $\begin{array}{l}2 \text { Type K } \\
\text { (bondline) }\end{array}$ & 60 and $100 \mathrm{sec}$ \\
\hline SRAM-14 & 4 & $1.0 \mathrm{in}$ & 2 & AHF & $\begin{array}{l}2 \text { Type K } \\
\text { (bondline) }\end{array}$ & $100 \mathrm{sec}$ \\
\hline SRAM-20 & 4 & $1.0 \mathrm{in}$ & 2 & $\mathrm{AHF}$ & $\begin{array}{l}2 \text { Type K } \\
\text { (bondline) }\end{array}$ & $100 \mathrm{sec}$ \\
\hline SLA -561V & 4 & $0.5 \mathrm{in}$ & 2 & AHF & $\begin{array}{l}2 \text { Type K } \\
\text { (bondline) }\end{array}$ & 60 and $100 \mathrm{sec}$ \\
\hline SLA -561V & 4 & $1.0 \mathrm{in}$ & 2 & $\mathrm{AHF}$ & $\begin{array}{l}2 \text { Type K } \\
\text { (bondline) }\end{array}$ & $100 \mathrm{sec}$ \\
\hline
\end{tabular}




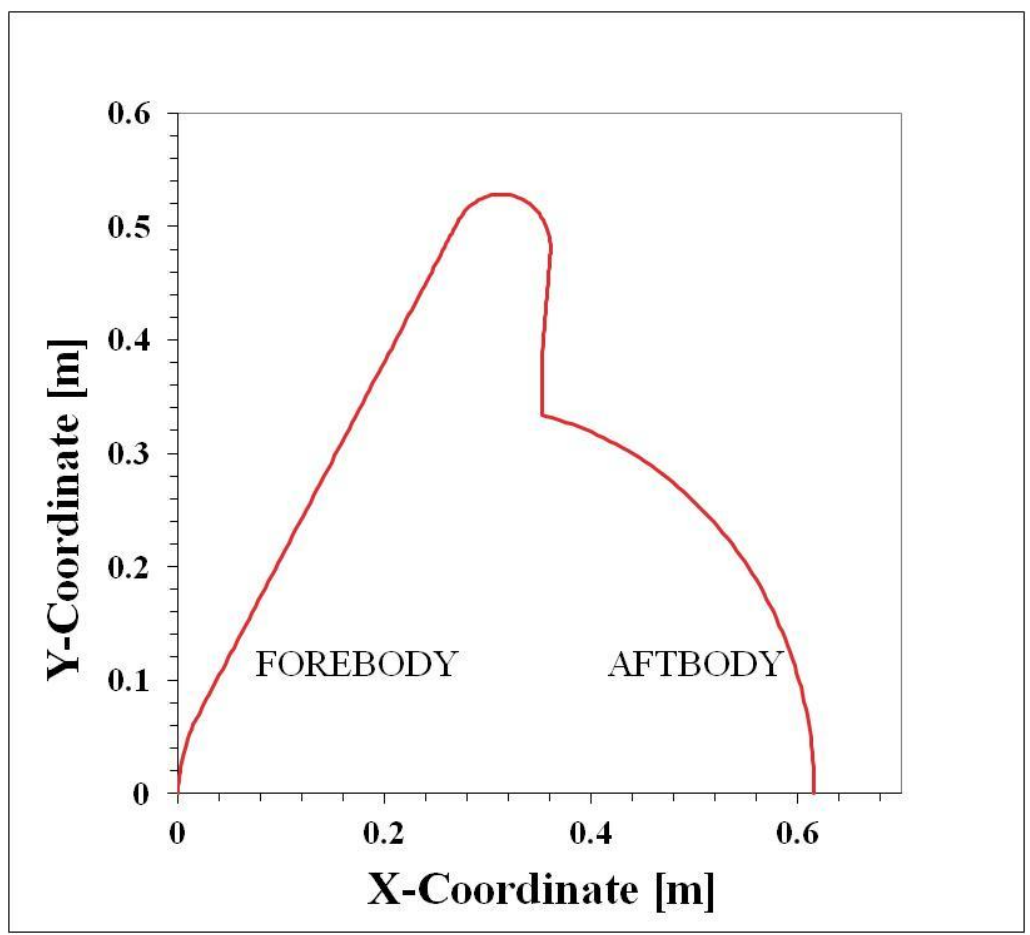

Figure 10: Entry vehicle contour for CFD analysis.
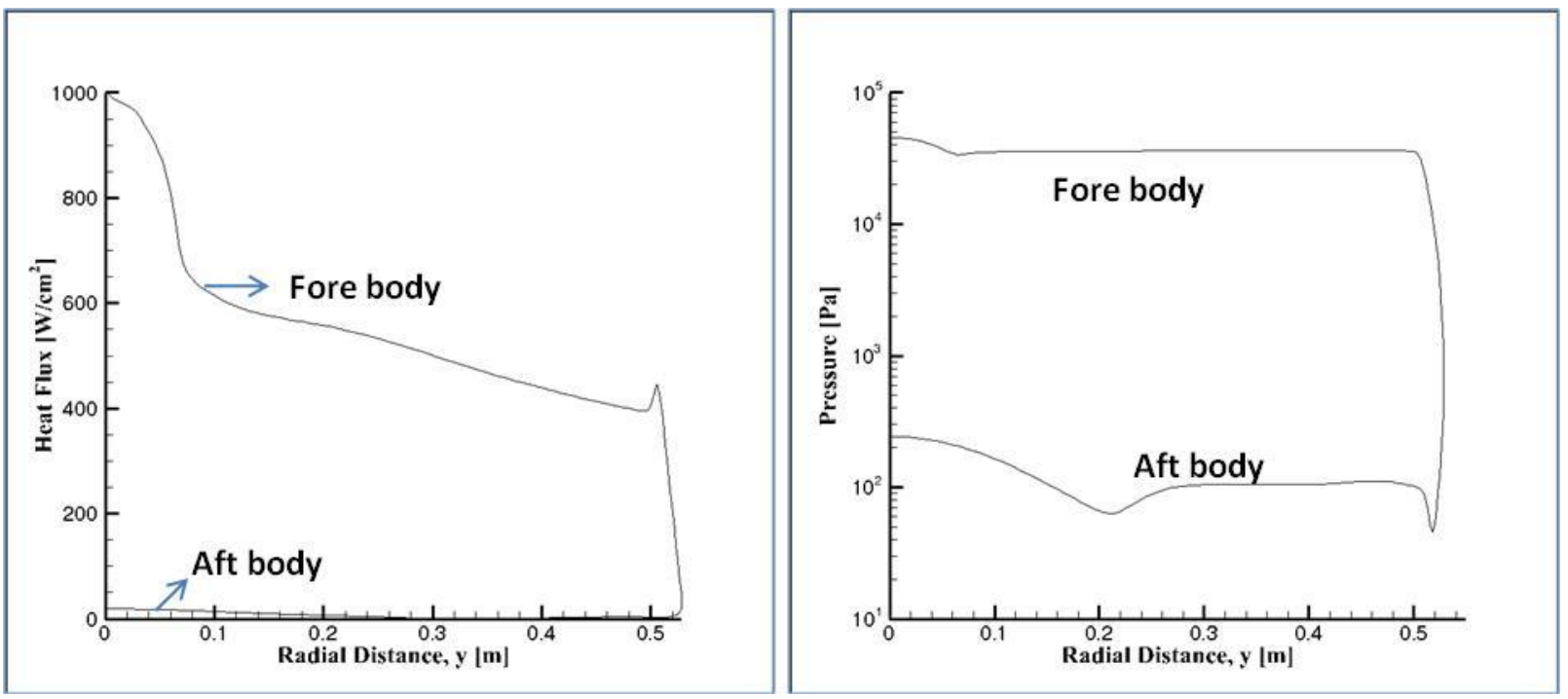

Figure 11: Environments from a nominal MSR trajectory. (a) Heat flux distribution (b) Pressure distribution

\section{Arcjet Test Results and Discussions}

The forebody material candidates Carbon-Carbon and Phencarb were successfully tested at the IHF with the 13.0 inch $(33.0 \mathrm{~cm})$ nozzle. For facility calibration to achieve the desired test conditions (condition \# 1 listed in Table 2), 4.0 inch $(10.16 \mathrm{~cm})$ flat-faced calorimeters were used with some of the test runs. The aftbody candidates were tested at the AHF with the 18.0 inch $(45.7 \mathrm{~cm}$ ) nozzle and facility calibrations to achieve desired test conditions (condition \# 2 in Table 2) were performed using 5.0 inch $(12.7 \mathrm{~cm})$ flat-faced calorimeters. In both the facilities the desired test conditions were satisfactorily achieved within 5\%-10\% difference of target heatflux and pressure. 
The temperature at the surface of the samples was measured by pyrometers and an infrared camera. The temperature at the bottom of TPS samples (interface between the TPS material and aluminum plate) was measured using embedded bond-line thermocouples. In order to investigate the damage growth and its influence on the samples, laser surface scans and CT scans were performed before and after the arcjet tests, and a comparative analysis was performed for both the scans. The results for each of the candidate materials are discussed in the subsections below.

\section{A. Carbon-Carbon}

There were 11 samples, one control without any damage and ten samples with cavities that were exposed in the IHF as mentioned in Table 4. The exposure time for all but one sample was for 30 seconds. One sample had a longer exposure time of 40 seconds. The test runs were successful as all the samples survived the exposure without showing any catastrophic failure. Most of the samples showed the carbon layers peeling off from the top surface. Figure 11 shows the pictures before, during, and after the arcjet exposure. The cavities in all the samples grew due to the plasma exposure. The comparison of surface temperature contours from the IR camera for the control sample and the one with the damage are shown in Figure 12. The temperature contours clearly show about 200 deg C higher temperature around the MMOD cavities that could have caused further growth in size and depth. The presence of MMOD cavities didn't cause change in peak bondline temperature. However, we observed that cool-down took significantly longer for all the samples that had the MMOD cavities compared to the control sample. Figure 13 shows the bondline thermocouple data for the two samples.

The CT scan and laser scan data comparison for pre- and post arcjet exposure shows that cavities doubled in size in the $\mathrm{x}$-y plane. Table 4 lists the cavity dimensions due to MMOD impact prior to and after the arcjet tests. The irradiation did not seem to have any visible affect on the TPS performance. The CT scans of one of the C-C sample before and after arcjet tests is shown in Figure 14. The figure provides a clear evidence of in-depth cavity growth due to arcjet exposure. The damage growth in $\mathrm{C}-\mathrm{C}$ system could be of significant concern for missions with high probability of MMOD damage to thermal protection systems.

Table 4: Pre- and post-arcjet cavity dimensions of Carbon-Carbon samples.

\begin{tabular}{|c|c|c|c|c|c|c|c|c|c|c|c|}
\hline Model ID & $\begin{array}{c}\text { Exposure } \\
\text { (sec) }\end{array}$ & $\begin{array}{l}\text { Impact } \\
\text { Angle }\end{array}$ & $\begin{array}{l}\text { Irradiation } \\
(\mathrm{Y} / \mathrm{N})\end{array}$ & Coating & $\begin{array}{c}\text { Pre-test } \\
\text { cavity } \\
\text { depth }(\mathrm{cm})\end{array}$ & $\begin{array}{c}\text { Pre-test } \\
\text { cavity } \\
\text { length }(\mathrm{cm})\end{array}$ & $\begin{array}{c}\text { Pre-test } \\
\text { cavity } \\
\text { width }(\mathrm{cm})\end{array}$ & $\begin{array}{c}\text { Post-test } \\
\text { cavity } \\
\text { depth }(\mathrm{cm})\end{array}$ & \begin{tabular}{|c|} 
Post-test \\
cavity \\
length $(\mathrm{cm})$
\end{tabular} & $\begin{array}{c}\text { Post-test } \\
\text { cavity } \\
\text { width }(\mathrm{cm})\end{array}$ & comments \\
\hline C-C 1 & 30 & 0 & $\mathrm{Y}$ & $\mathrm{N}$ & Unknown & 0.44 & 0.58 & 2.64 & 0.82 & 1.20 & cavity growth \\
\hline $\mathrm{C}-\mathrm{C} 2$ & 30 & 0 & $\mathrm{~N}$ & $\mathrm{~N}$ & Unknown & 0.43 & 0.55 & 2.62 & 0.73 & 0.90 & cavity growth \\
\hline $\mathrm{C}-\mathrm{C} 3$ & 30 & 0 & $\mathrm{Y}$ & $\mathrm{N}$ & Unknown & 0.58 & 0.49 & 2.90 & 1.17 & 1.30 & cavity growth \\
\hline C-C 4 & 30 & 60 & $\mathrm{Y}$ & $\mathrm{N}$ & Unknown & 0.43 & 0.62 & 3.08 & 1.11 & 1.10 & cavity growth \\
\hline C-C 5 & 30 & Unknown & $\mathrm{N}$ & $\mathrm{N}$ & Unknown & 0.41 & 0.58 & 3.39 & 1.08 & 1.22 & cavity growth \\
\hline $\mathrm{C}-\mathrm{C} 6$ & 30 & 0 & $\mathrm{~N}$ & $\bar{Y}$ & Unknown & 0.58 & 0.59 & 2.67 & 1.05 & 0.96 & cavity growth \\
\hline C-C 7 & 30 & 0 & $\mathrm{~N}$ & $\mathrm{~N}$ & Unknown & 0.52 & 0.56 & 2.53 & 1.02 & 1.11 & cavity growth \\
\hline C-C 8 & 40 & 60 & $Y$ & $\mathrm{Y}$ & Unknown & 0.96 & 0.94 & 3.52 & 1.40 & 1.43 & cavity growth \\
\hline C-C 9 & 30 & 60 & $\mathrm{~N}$ & $\mathrm{Y}$ & Unknown & 0.93 & 1.02 & 3.34 & 1.46 & 1.42 & cavity growth \\
\hline C-C 10 & 30 & Unknown & $\mathrm{N}$ & $\mathrm{Y}$ & Unknown & 0.90 & 0.87 & 2.65 & 0.99 & 1.02 & cavity growth \\
\hline
\end{tabular}
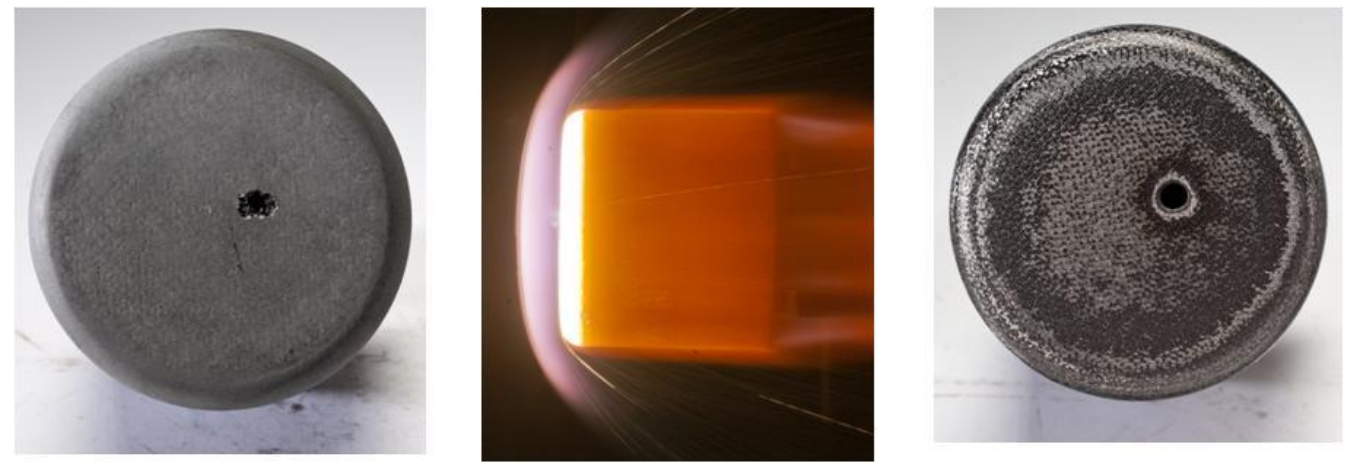

Figure 12: carbon-Carbon sample before, during, and after the arcjet test. 

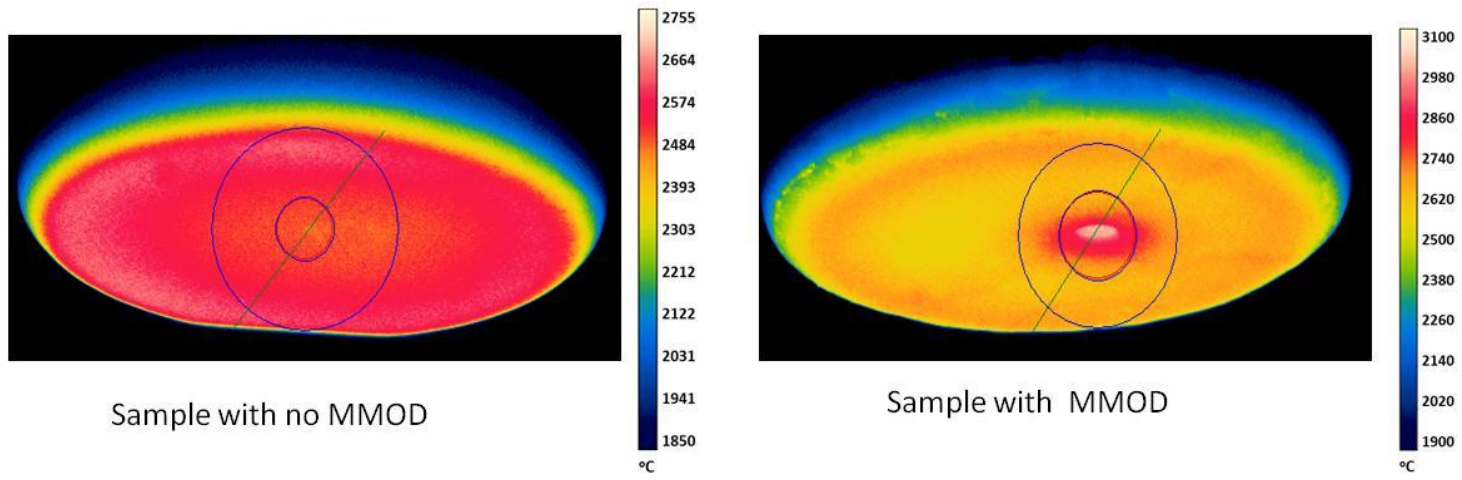

Figure 13: IR data of C-C samples showing higher temperature near the cavity during IHF testing.

C-C sample: No MMOD damage

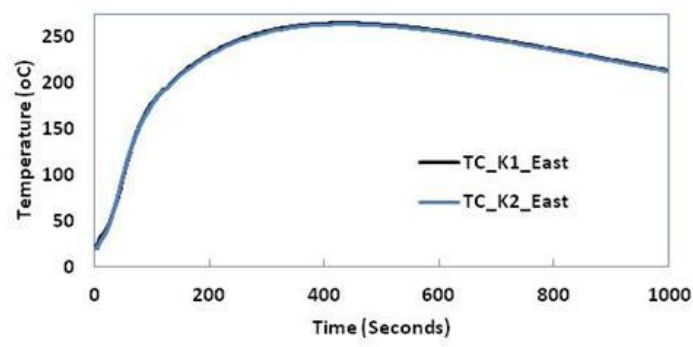

C-C sample: MMOD damage

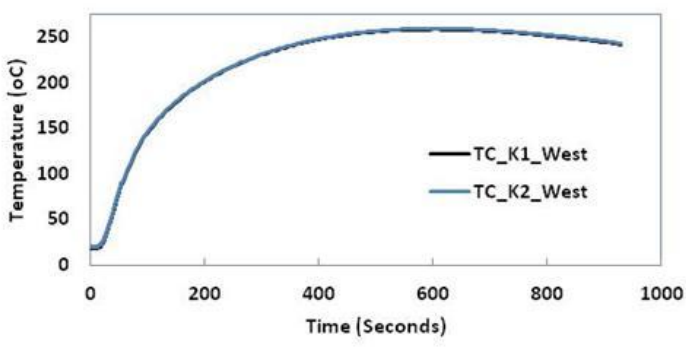

Figure 14: Bondline thermocouple data comparison for samples with and without the damage.
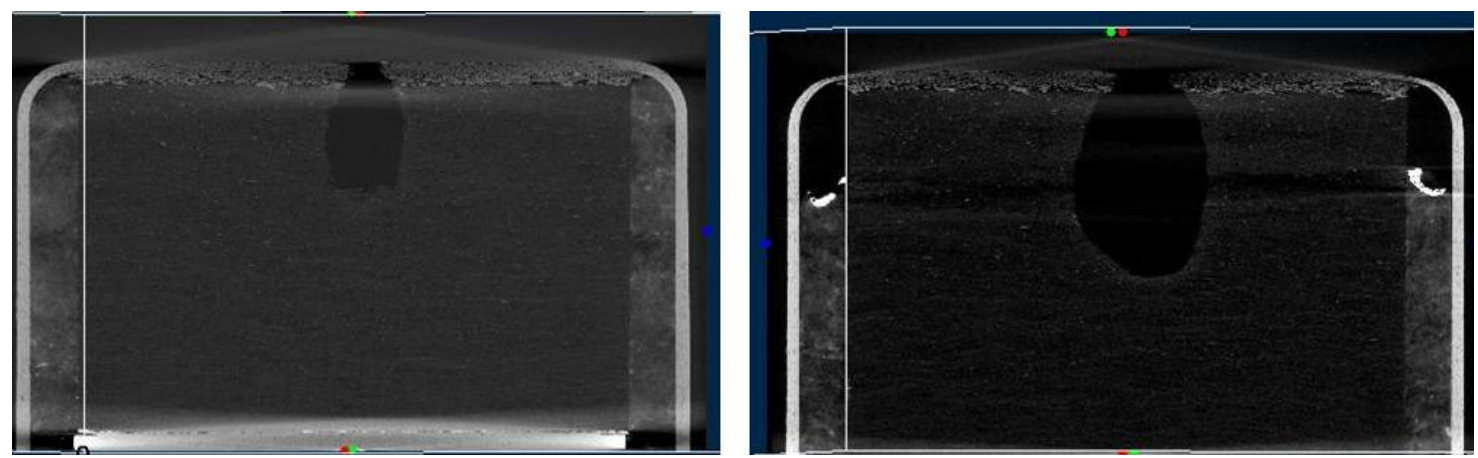

Figure 15: Pre- and Post-arcjet CT scans of Carbon-Carbon Sample.

\section{B. Phencarb}

Two different types of samples from the Phencarb family, Phencarb-24 and Phencarb-28, were selected for the test campaign in the IHF facility. As mentioned earlier, the constituents for both types are the same but the density for Phencarb-28 is $28.0 \mathrm{lb} / \mathrm{ft}^{3}\left(448 \mathrm{~kg} / \mathrm{m}^{3}\right)$ whereas the density of Phencarb-24 is $24.0 \mathrm{lb} / \mathrm{ft}^{3}\left(384 \mathrm{~kg} / \mathrm{m}^{3}\right)$. Ten samples; one control (without cavity) and four samples with MMOD cavity from each group were tested. Every sample was exposed in the arcjet environment for 60 seconds. The test runs were successful as all the samples survived the exposure without showing any catastrophic failure. All the samples with MMOD cavity were subjected to pre- and post-test laser scans. The cavity dimensions measured using laser scans and other details are listed in Table 5. Most (about 60\%) of the samples showed the cavity, partially filling up with ablator melt. In some cases damage disappeared due to the combination of recession and ablator melt. Table 5 also lists the samples that were irradiated prior to hypervelocity impact test. The radiation exposure did not seem to affect the TPS performance. 
Figure 16 shows the pictures of pre- and post-arcjet tested Phencarb samples where the MMOD cavity completely disappeared after the test. Figure 17 shows the line profile of laser surface scans of a pre- and post-arcjet Phencarb sample. The scans shows the partial filliung of caviries after the arcjet exposure due to ablator melting.. For only one sample there may have been a very slight increase in damage area but no changes in depth. Figure 18 shows the CT scan images of pre- and post-arcjet tested sample. The cavity depth decreases due to recession. The comparison of surface temperature contours from IR camera for the control sample and one with the damage are shown in Figure 19. For Phencarb samples, the temperature around the cavities was about $500^{\circ} \mathrm{C}$ lower compared to the rest of the sample surface, which turned out to be very different compared to C-C samples. No changes were observed in the bondline temperature history due to the presence of MMOD cavities as shown in Figure 20. The pyrometer data showed very similar surface temperatures for the samples. The test shows that Phencarb material can sustain MMOD impacts and does not pose any significant concerns for atmospheric entry heating in the presence of cavities.

Table 5: Pre- and post- arcjet cavity dimensions of Phencarb samples.

\begin{tabular}{|c|c|c|c|c|c|c|c|c|c|c|}
\hline Model ID & $\begin{array}{l}\text { Thickness } \\
(\mathrm{cm})\end{array}$ & $\begin{array}{l}\text { Impact } \\
\text { Angle }\end{array}$ & $\begin{array}{l}\text { Irradiation } \\
(\mathrm{Y} / \mathrm{N})\end{array}$ & $\begin{array}{c}\text { Pre-test } \\
\text { cavity } \\
\text { depth }(\mathrm{cm})\end{array}$ & $\begin{array}{c}\text { Pre-test } \\
\text { cavity } \\
\text { length }(\mathrm{cm})\end{array}$ & $\begin{array}{c}\text { Pre-test } \\
\text { cavity } \\
\text { width }(\mathrm{cm})\end{array}$ & $\begin{array}{c}\text { Post-test } \\
\text { cavity } \\
\text { depth }(\mathrm{cm})\end{array}$ & $\begin{array}{l}\text { Post-test } \\
\text { cavity } \\
\text { length }(\mathrm{cm})\end{array}$ & $\begin{array}{c}\text { Post-test } \\
\text { cavity } \\
\text { width }(\mathrm{cm})\end{array}$ & comments \\
\hline Phencarb 28-1 & 2.54 & $\mathrm{~N} / \mathrm{A}$ & & $\mathrm{N} / \mathrm{A}$ & N/A & $\mathrm{N} / \mathrm{A}$ & $\mathrm{N} / \mathrm{A}$ & N/A & N/A & no defect \\
\hline Phencarb 28-2 & 2.54 & 0 & $\mathrm{Y}$ & 0.94 & 0.67 & 0.46 & 0.21 & 0.64 & 0.52 & partial cavity filling \\
\hline Phencarb 28-3 & 2.54 & 60 & $\mathrm{~N}$ & 1.80 & 1.13 & 1.02 & - & - & - & $\begin{array}{l}\text { no defect due to recession and ablator } \\
\text { melt }\end{array}$ \\
\hline Phencarb 28-4 & 2.54 & 60 & $\mathrm{Y}$ & 0.39 & 1.17 & 0.98 & - & - & - & $\begin{array}{l}\text { no defect due to recession and ablator } \\
\text { melt }\end{array}$ \\
\hline Phencarb 24-1 & 2.54 & N/A & & N/A & N/A & N/A & N/A & N/A & N/A & no defect \\
\hline Phencarb 24-2 & 2.54 & 0 & $\mathrm{~N}$ & 1.21 & 0.76 & 0.85 & 0.34 & 0.69 & 0.85 & partial cavity filling \\
\hline Phencarb 24-3 & 2.54 & 0 & $\mathrm{Y}$ & 1.21 & 0.73 & 0.84 & 0.53 & 0.87 & 1.07 & absolute cavity depth similar \\
\hline Phencarb 24-4 & 2.54 & 60 & $\mathrm{Y}$ & 0.57 & 0.96 & 0.87 & - & - & - & recess further than cavity \\
\hline Phencarb 24-5 & 2.54 & 60 & $\mathrm{~N}$ & 0.49 & 1.05 & 1.20 & - & - & - & recess further than cavity \\
\hline Phencarb 28-5 & 2.54 & 0 & $\mathrm{~N}$ & 0.95 & 0.91 & 1.07 & 0.44 & 0.73 & 0.75 & partial cavity filling \\
\hline
\end{tabular}
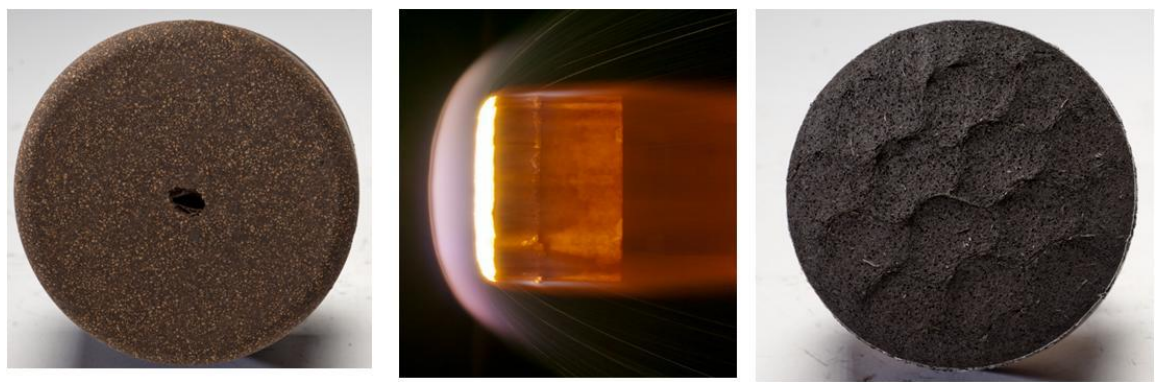

Figure 16: Phencarb sample before, during and after the arcjet test.

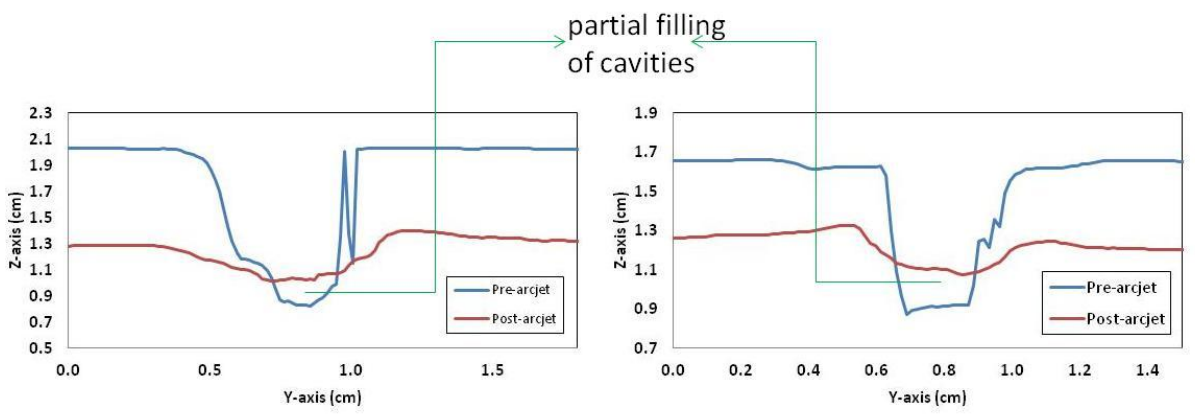

Figure 17: Laser scan of pre- and post-arcjet Phencarb samples. 

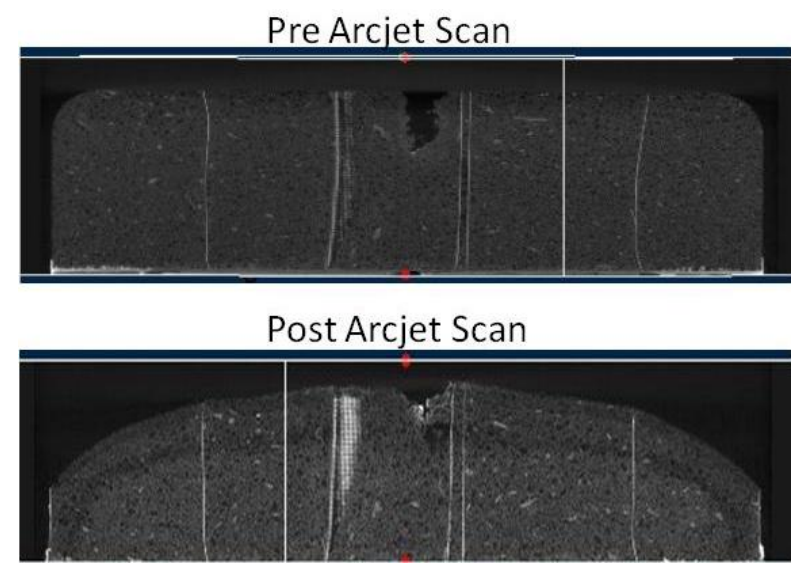

Figure 18: CT scan of a pre- and post-arcjet Phencarb sample.
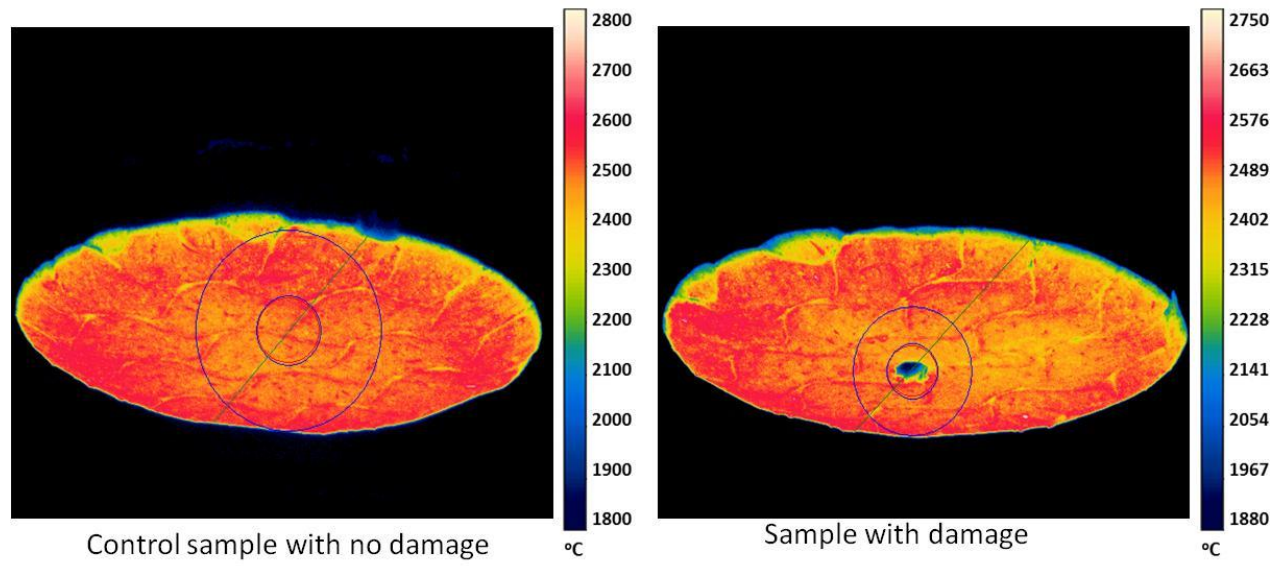

Figure 19: IR data of Phencarb samples showing cooler cavity during IHF testing.
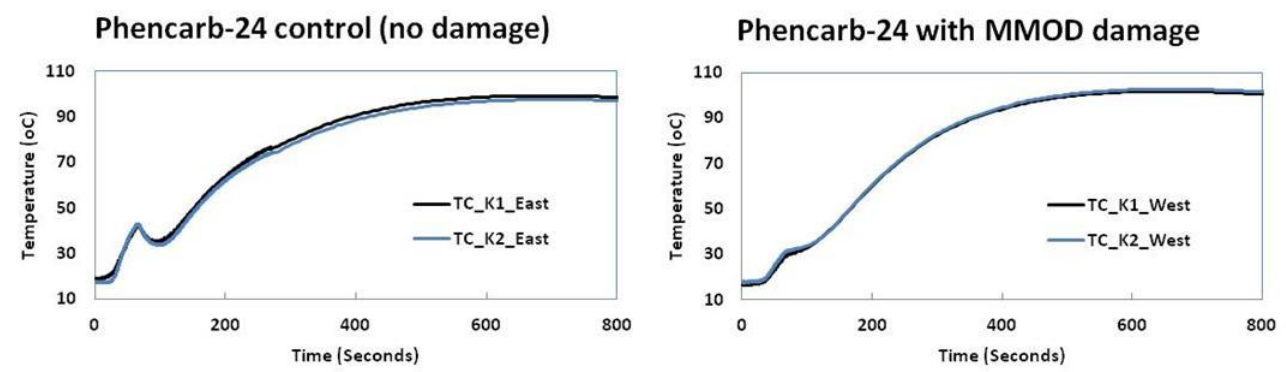

Figure 20: Bondline thermocouple data comparison for Phencarb samples with and without the damage.

\section{SLA-561V}

Nine SLA-561V samples, including one control without MMOD cavity were tested in the AHF facility with the 18.0 inch $(45.72 \mathrm{~cm})$ nozzle. The pre-test laser scans showed depth of the cavities in the range of $0.635 \mathrm{~cm}$ to $1.78 \mathrm{~cm}$. In some of the samples with $1.42 \mathrm{~cm}$ height, the cavities went through the entire thickness of the TPS and the aluminum interface plate could be seen.

All the $2.54 \mathrm{~cm}$ samples were exposed in the arcjet environment for 100 seconds. These samples survived the exposure without showing any catastrophic failure or damage growth. Three SLA samples with $1.42 \mathrm{~cm}$ height, including the control sample, were exposed for 60 seconds. When no significant failure was witnessed during the 60 second exposure, the remaining two were exposed for 100 seconds. No evidence of flow-through in the samples was observed. Figure 21 shows one of the SLA samples before, during, and after the test. The surface temperature contours measured by IR camera show that in and around the cavity, the surface temperatures were about $200^{\circ} \mathrm{C}$ lower compared to the rest of the sample surface as shown in Figure 22. 
All eight samples with MMOD cavities were subjected to pre- and post-test laser scans. The cavity dimensions and data are shown in Table 6. It also shows the samples that were irradiated. The radiation exposure does not seem to affect the TPS performance. Three out of eight samples showed either no change or $10 \%$ decrease due to ablator melting and filling the cavity. Figure 23 shows the evidence of partial cavity filling. One sample (SLA-6) showed substantial growth in the surface area but no growth in depth. Only one sample showed a 50\% increase in depth. Three out of eight samples showed a very small increase (12\%) in damage area. The bondline temperature history does not show any changes due to the presence of MMOD cavity as shown in Figure 24. This test shows, while there is a small probability of $12 \%-50 \%$ growth in the cavities there is no catastrophic failure or cause of significant concerns due to presence of MMOD like damage in the SLA-561V material performance during entry.

Table 6: Pre- and post- arcjet cavity dimensions of SLA-561V samples.

\begin{tabular}{|c|c|c|c|c|c|c|c|c|c|c|c|}
\hline Model ID & $\begin{array}{l}\text { Exposure } \\
\text { (sec) }\end{array}$ & $\begin{array}{l}\text { Thickness } \\
\text { (cm) }\end{array}$ & $\begin{array}{l}\text { Impact } \\
\text { Angle }\end{array}$ & $\begin{array}{c}\text { Irradiation } \\
(\mathrm{Y} / \mathrm{N})\end{array}$ & \begin{tabular}{|c|} 
Pre-test \\
cavity \\
depth $(\mathrm{cm})$ \\
\end{tabular} & \begin{tabular}{|c|} 
Pre-test \\
cavity \\
length $(\mathrm{cm})$
\end{tabular} & $\begin{array}{c}\text { Pre-test } \\
\text { cavity } \\
\text { width }(\mathrm{cm})\end{array}$ & \begin{tabular}{|c|} 
Post-test \\
cavity \\
depth $(\mathrm{cm})$
\end{tabular} & \begin{tabular}{|c|} 
Post-test \\
cavity \\
length $(\mathrm{cm})$
\end{tabular} & $\begin{array}{c}\text { Post-test } \\
\text { cavity } \\
\text { width }(\mathrm{cm})\end{array}$ & Comments \\
\hline SLA-1 & 100 & 2.54 & 0 & $\mathrm{~N}$ & 1.40 & 0.62 & 0.54 & 1.26 & 0.61 & 0.54 & $\begin{array}{l}\text { modest decrease in defect depth despite } \\
\text { slight acreage recession }\end{array}$ \\
\hline SLA-2 & 100 & 2.54 & 60 & $\mathrm{~N}$ & 0.83 & 1.12 & 0.93 & 0.85 & 1.20 & 1.02 & $\begin{array}{l}\text { slight increase in defect area coupled } \\
\text { with slight acreage recession }\end{array}$ \\
\hline SLA-3 & 100 & 2.54 & 0 & $\mathrm{Y}$ & 1.09 & 0.83 & 0.43 & 1.11 & 0.81 & 0.51 & $\begin{array}{l}\text { modest increase in defect area coupled } \\
\text { with slight acreage recession }\end{array}$ \\
\hline SLA-4 & 100 & 2.54 & 60 & $\mathrm{Y}$ & 0.77 & 1.34 & 1.19 & 0.82 & 1.35 & 1.23 & $\begin{array}{l}\text { slight increase in defect depth coupled } \\
\text { with slight acreage recession }\end{array}$ \\
\hline SLA-5 & 60 & 1.42 & N/A & $\mathrm{N} / \mathrm{A}$ & N/A & $\mathrm{N} / \mathrm{A}$ & $\mathrm{N} / \mathrm{A}$ & $\mathrm{N} / \mathrm{A}$ & N/A & N/A & Control \\
\hline SLA-6 & 60 & 1.42 & 0 & $\mathrm{~N}$ & 1.21 & 0.69 & 0.59 & 1.18 & 1.09 & 0.88 & $\begin{array}{l}\text { substantial increase in defect area } \\
\text { coupled with slight acreage recession }\end{array}$ \\
\hline SLA-7 & 100 & 1.42 & 60 & $\mathrm{~N}$ & 1.02 & 1.46 & 1.21 & 1.02 & 1.52 & 1.33 & $\begin{array}{l}\text { modest increase in defect area coupled } \\
\text { with slight acreage recession }\end{array}$ \\
\hline SLA-8 & 60 & 1.42 & 0 & $\mathrm{Y}$ & 1.24 & 0.72 & 0.60 & 1.21 & 0.74 & 0.56 & $\begin{array}{l}\text { slight decrease in defect area and slight } \\
\text { acreage recession }\end{array}$ \\
\hline SLA-9 & 100 & 1.42 & 60 & Y & 0.95 & 1.37 & 1.18 & 0.93 & 1.35 & 1.17 & $\begin{array}{l}\text { no noticeable defect change and slight } \\
\text { acreage recession }\end{array}$ \\
\hline
\end{tabular}
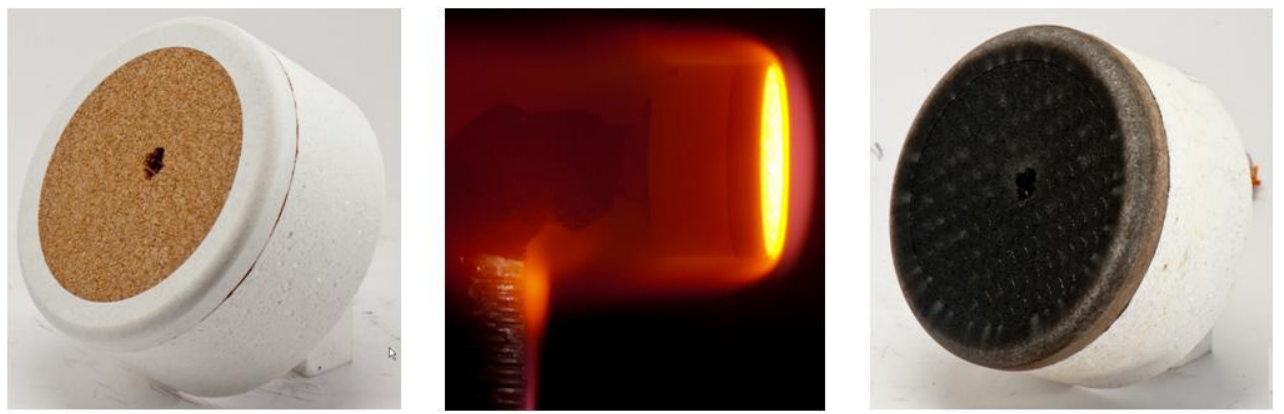

Figure 21: SLA sample before, during, and after the arcjet test.

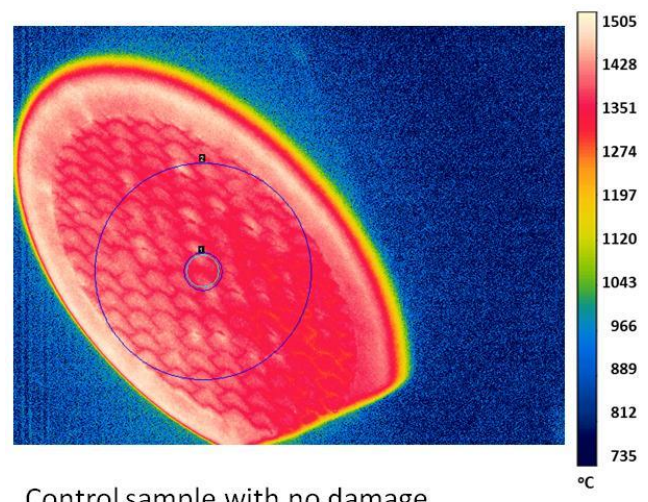

Control sample with no damage

(a)

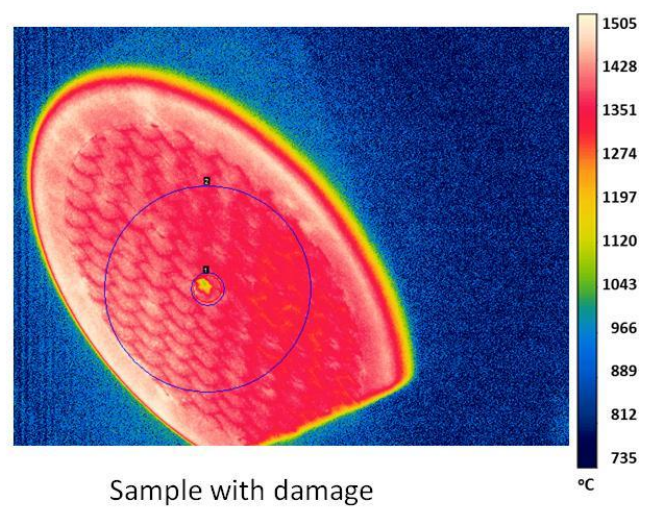

(b)

Figure 22: IR data of SLA samples showing cooler cavity during IHF testing.(a) No Damage (b) With Cavity at the center. 


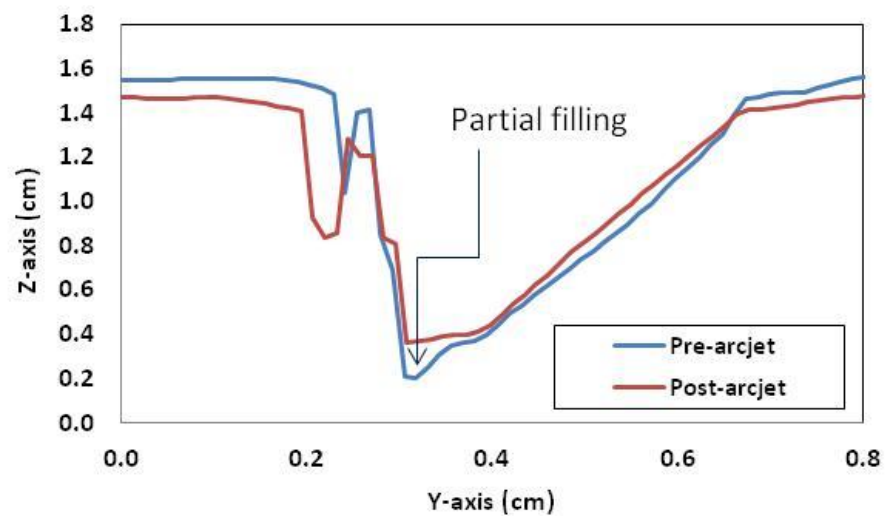

Figure 23: Laser scan of pre- and post-arcjet SLA-561V sample.
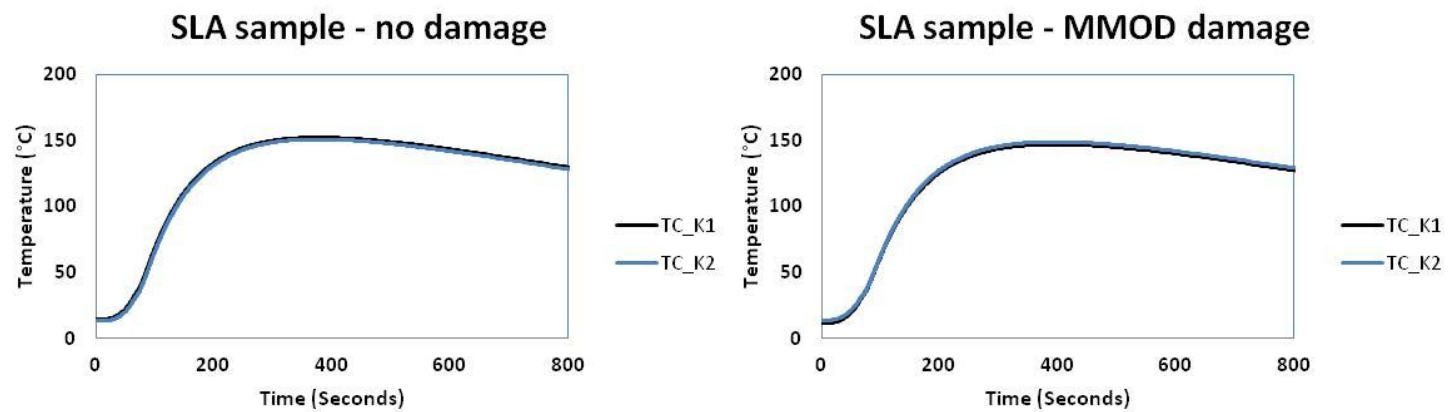

Figure 24: Bondline thermocouple data comparison for SLA samples with and without the damage.

\section{SRAM}

There were total 12 SRAM samples; eight SRAM-14 and four SRAM-20, tested in the AHF facility at $60 \mathrm{~W} / \mathrm{cm}^{2}$ heatflux. The sample heights and exposure time are provided in Table 7. Unfortunately, for this family we did not have a control sample to compare the data. The pre-test laser scans showed cavity depths in the range of 0.76 to 1.27 $\mathrm{cm}$. For some of the $1.27 \mathrm{~cm}$-SRAM samples the cavity depth reached the bottom of TPS and the metallic interface was visible.

All the samples survived the tests; however, we did witness some flames leaping out of the cavity which would indicate burning of the ablator. Figure 25 shows one of the SRAM samples before, during, and after the test. Figure 26 shows the infrared measurement on the sample. The cavity is $200^{\circ} \mathrm{C}$ cooler compared to the rest of the surface. The bondline temperature history is shown in Figure 27. No significant rise in temperature was observed at the bondline due to the presence of cavity. Table 7 provides the cavity dimensions and other details before and after the arcjet testing. Six out of twelve samples (50\% of the samples) either did not show any changes or a slight filling of the cavity due to ablator melting. Five samples showed $12 \%$ increase in either depth or damage area. Only one 2.54 $\mathrm{cm}$ thick SRAM sample showed a significant (150\%) increase in depth and 17\% increase in the area after arcjet exposure. Figure 28a shows laser scan profile of the sample where significant increase in depth was observed. In contrast figure $28 \mathrm{~b}$ shows the decrease in depth due to partial filling of the cavities. Figure 29 shows the cavity growth captured by the laser scans in the SRAM sample. Table 7 also shows the samples that were exposed to the radiation prior to hypervelocity impact test. The irradiation did not seem to affect the TPS performance. The results from the arcjet test reveal that one needs to be aware of a small probability of cavity growth when selecting SRAM materials for missions with MMOD risks and address mitigation plans. 
Table 7: Pre- and post- arcjet cavity dimensions of SRAM samples.

\begin{tabular}{|c|c|c|c|c|c|c|c|c|c|c|c|}
\hline Model ID & $\begin{array}{l}\text { Exposure } \\
\text { (sec) }\end{array}$ & $\begin{array}{l}\text { Thickness } \\
\text { (cm) }\end{array}$ & $\begin{array}{l}\text { Impact } \\
\text { Angle }\end{array}$ & $\begin{array}{c}\text { Irradiation } \\
(\mathrm{Y} / \mathrm{N})\end{array}$ & $\begin{array}{l}\text { Pre-test } \\
\text { cavity } \\
\text { depth }(\mathrm{cm})\end{array}$ & \begin{tabular}{|c|}
$\begin{array}{c}\text { Pre-test } \\
\text { cavity } \\
\text { length }(\mathrm{cm})\end{array}$ \\
\end{tabular} & $\begin{array}{l}\text { Pre-test } \\
\text { cavity } \\
\text { width }(\mathrm{cm})\end{array}$ & \begin{tabular}{|c|} 
Post-test \\
cavity \\
depth $(\mathrm{cm})$
\end{tabular} & \begin{tabular}{|c|}
$\begin{array}{c}\text { Post-test } \\
\text { cavity } \\
\text { length }(\mathrm{cm})\end{array}$ \\
\end{tabular} & $\begin{array}{l}\text { Post-test } \\
\text { cavity } \\
\text { width }(\mathrm{cm})\end{array}$ & Comments \\
\hline SRAM 14-1 & 100 & 2.54 & N/A & & N/A & N/A & N/A & N/A & N/A & N/A & Control \\
\hline SRAM 14-2 & 100 & 2.54 & 60 & $\mathrm{~N}$ & 0.92 & 1.60 & 1.07 & 1.04 & 1.60 & 1.05 & modest increase in defect depth \\
\hline SRAM 14-3 & 100 & 2.54 & 0 & $\mathrm{Y}$ & 0.54 & 1.55 & 1.01 & 1.37 & 1.60 & 1.18 & $\begin{array}{l}\text { very substantial increase in defect } \\
\text { depth and modest increase in area }\end{array}$ \\
\hline SRAM 14-4 & 100 & 2.54 & 60 & $\mathrm{Y}$ & 0.88 & 1.59 & 1.37 & 1.00 & 1.60 & 1.39 & modest increase in defect depth \\
\hline SRAM 14-5 & 100 & 2.54 & 0 & $\mathrm{~N}$ & 1.82 & 0.86 & 0.85 & 1.56 & 0.84 & 0.81 & modest decrease in defect depth \\
\hline SRAM 20-1 & 100 & 2.54 & 0 & $\mathrm{~N}$ & 0.93 & 0.62 & 0.60 & 0.94 & 0.72 & 0.63 & $\begin{array}{l}\text { modest increase in defect area as a } \\
\text { result of recession at the defect } \\
\text { perimeter (i.e. ablative filler receding at } \\
\text { the honeycomb cell wall) }\end{array}$ \\
\hline SRAM $20-2$ & 100 & 2.54 & 0 & $\mathrm{Y}$ & 1.34 & 0.51 & 0.51 & 1.32 & 0.52 & 0.49 & no noticeable change \\
\hline SRAM 20-3 & 100 & 2.54 & 60 & $\mathrm{~N}$ & 0.71 & 1.27 & 0.82 & 0.72 & 1.27 & 0.87 & slight increase in defect width \\
\hline SRAM 20-4 & 100 & 2.54 & 60 & $\mathrm{Y}$ & 0.66 & 1.41 & 0.85 & 0.69 & 1.40 & 0.85 & no noticeable change \\
\hline SRAM 14-6 & 60 & 1.27 & 60 & $\mathrm{Y}$ & 1.04 & 2.06 & 1.21 & 1.05 & 2.04 & 1.23 & no noticeable change \\
\hline SRAM 14-7 & 60 & 1.27 & 60 & $\mathrm{~N}$ & 0.97 & 1.83 & 1.54 & 1.10 & 1.96 & 1.76 & modest increase in defect depth, area \\
\hline SRAM $14-8$ & 100 & 1.27 & 0 & $\mathrm{Y}$ & 1.33 & 1.11 & 0.78 & 1.25 & 1.10 & 0.77 & $\begin{array}{l}\text { slight decrease in defect depth possibly } \\
\text { as a result of silica melt accumulations } \\
\text { (at the top surface of the honeycomb) } \\
\text { blocking the laser plane from reaching } \\
\text { the deepest part of the defect floor) }\end{array}$ \\
\hline SRAM $14-9$ & 100 & 1.27 & 0 & $\mathrm{~N}$ & 1.28 & 1.00 & 0.89 & 1.26 & 1.01 & 0.88 & no noticeable change \\
\hline
\end{tabular}
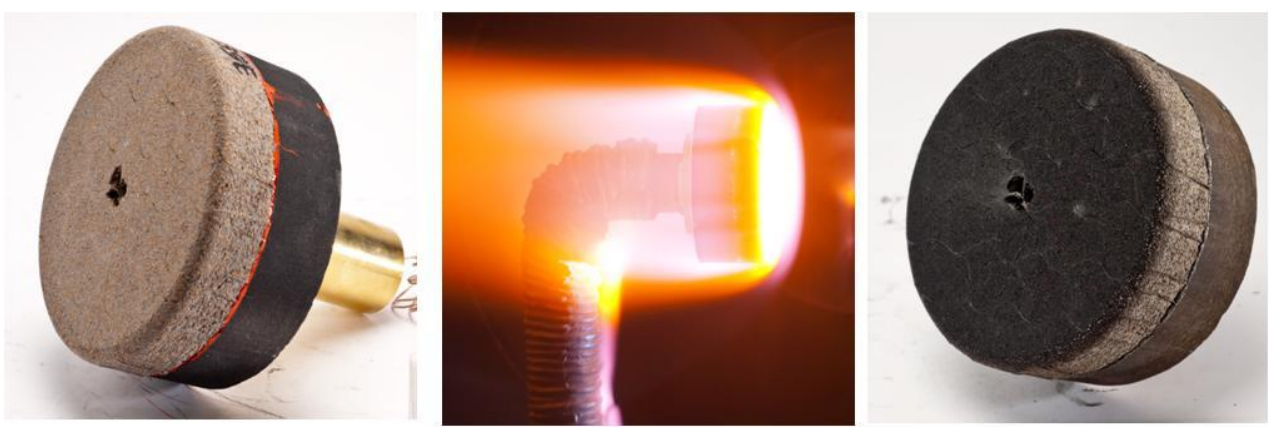

Figure 25: SRAM sample before, during and after the arcjet test.

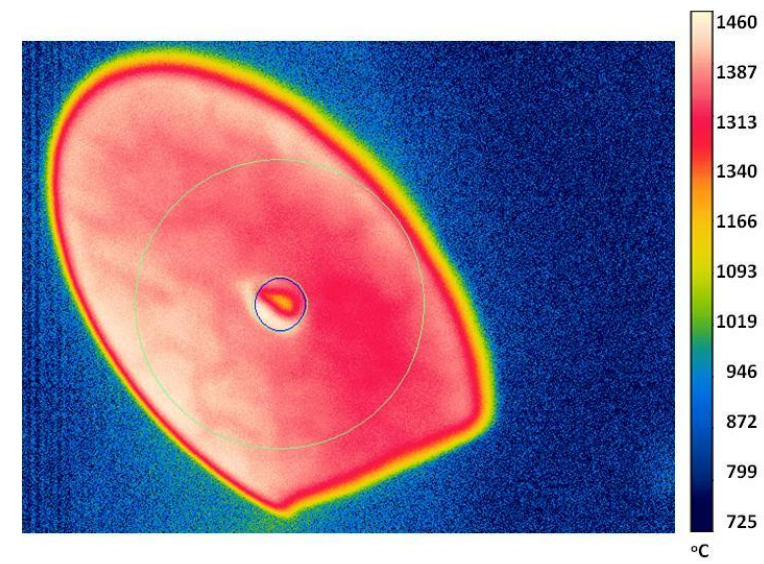

Figure 26: Infrared measurements of a SRAM sample during arcjet test. 


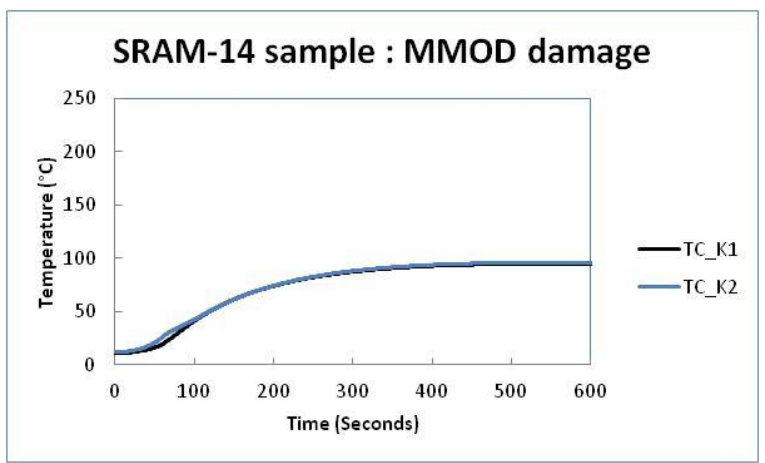

Figure 27: Temperature history at the bondline.

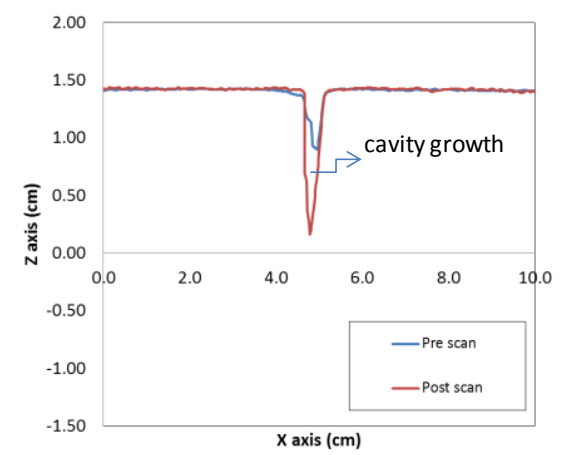

(a)

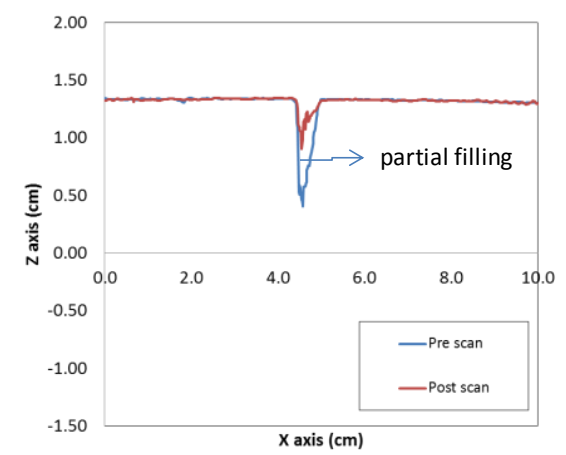

(b)

Figure 28: Laser scan profile of SRAM samples. (a) Cavity growth (b) Partial filling.
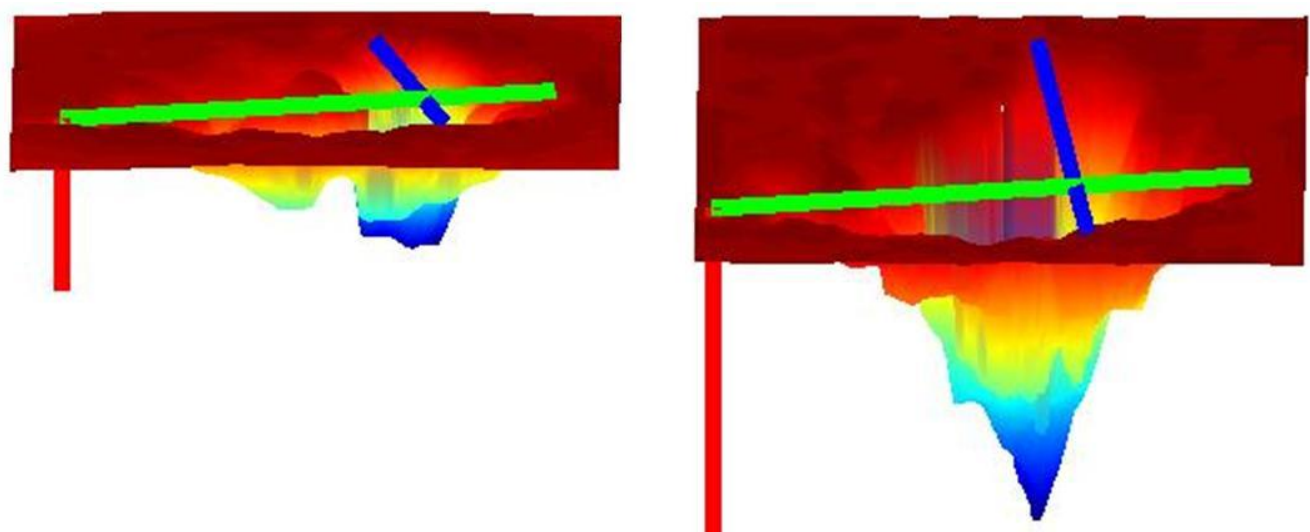

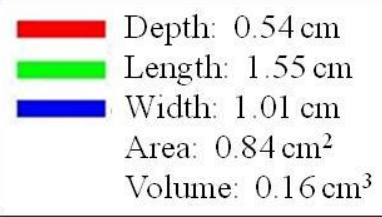

Pre-test scan

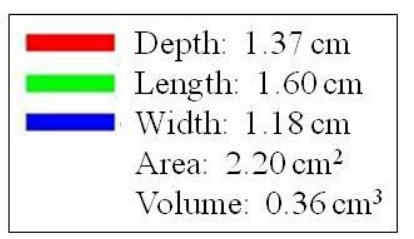

Post-test scan

Figure 29: Contour plots of cavities showing growth in one of the SRAM sample after arcjet test.

\section{Summary and Conclusions}

The Space Environment Effects (SEE) test campaign was successfully accomplished with the completion of arcjet testing of several candidate TPS materials. None of the materials showed a catastrophic failure during the 
arcjet test due to the presence of the cavities. The Phencarb TPS showed the most promising result, suggesting that for missions where MMOD is a major concern, use of ablative TPS that undergoes melting during entry could be very beneficial. The test data suggests that the Carbon-Carbon system was most affected by the MMOD impact as well as the subsequent arcjet testing. The study indicates that $\mathrm{C}-\mathrm{C}$ system will need more optimization for missions with MMOD threats. The SLA and SRAMs samples showed a small probability of damage growth that needs to be addressed when selecting these materials as TPS candidates for missions with higher probability of MMOD damage. The present study provides valuable information regarding the capability of various thermal protection materials that are critical to aerocapture sample return and other planetary entry missions.

\section{Acknowledgments}

This work was supported by the In-Space Propulsion Technology Program and by NASA STRAD contract no. NNA10DE12C to ERC, Incorporated. The authors acknowledge the support of Bill Congdon from ARA, Jarvis Songer and Bill Willcockson from Lockheed Martin for providing the samples and relevant information to support the tests. Authors also acknowledge the support of several engineers and research staff at NASA Ames and NASA Langley including Gary Allen, John Pham, Imelda Terrazas-Salinas, Frank Hui, Matt Switzer, Patricia Howell, Dinesh Prabhu and Jose Aliaga for providing support to successfully conduct the tests. We also acknowledge NASA-SCAP for their critical financial support of the arcjet operational capability at NASA Ames Research Center.

\section{References}

${ }^{1}$ Anderson, D. J. et. al., "NASA In-Space Propulsion Technologies and Their Infusion Potential”, AIAA 2012-4288, August 2012.

${ }^{2}$ Munk, M. M. and Moon, S.A., “Aerocapture Technology Developments Overview”, IEEEAC paper \#1447, December 2007.

${ }^{3}$ Anderson, B. J. and Smith, R.E., "Natural Orbital Environment Guidelines for Use in Aerospace Vehicle Development”, NASA TM-4527, June 1994.

${ }^{4}$ Mcnamara, H.A. et. al., "Meteoroid Engineering Model (MEM): A Meteoroid model for the inner solar system", Earth, Moon and Planets, Vol 95, December 2004, pp 123-139.

${ }^{5}$ Chhabildas, L. and Orphal, D., "Survey of the Hypervelocity Impact Technology and Applications", Sandia Report, SAND2006-3087, May 2006.

${ }^{6}$ W.M.Congdon, "Family Systems of Advanced Charring Ablators for PlanetaryAerocapture and Entry Missions," NASA Science Technology Conference 2007, D8P2, University of Maryland, June 2007.

${ }^{7}$ National Aeronautics and Space Administration, “Genesis Launch”, Press Kit \#1, July 2001.

${ }^{8}$ Laub B., Chen Y.K., "TPS Challenges for Neptune Aerocapture”, AIAA 2004-5178, August 2004.

${ }^{9}$ Tran. H., et. al., “Ames Research Center Shear Tests of SLA-561V Heat ShieldMaterial for Mars-Pathfinder”, NASA TM$110402,1996$.

${ }^{10}$ Peterson, A. B., Nichols, F., Mifsud, B., and Love,W., "Arc Jet Testing in NASA Ames Research Center Thermophysics Facilities," AIAA paper 92-5041, Dec. 1992.

${ }^{11}$ Laub, B., Balboni, J. and Goldstein, H., "Ground T est Facilities for TPS Development," NASA TM-2002-211400, NASA Ames Research Center, Moffett Field, California, May 2002.

${ }^{12}$ Agrawal P., et. al. "Thermal Soak Analysis of Earth Entry Vehicles”, AIAA 2012-3010, June 2012. 